\title{
THE NATIONAL AIR EMISSIONS MONITORING STUDY’S SOUTHEAST LAYER Site: PART I. Site CHARACTERISTICS AND MONITORING METHODOLOGY
}

\author{
L. Wang-Li, Q.-F. Li, K. Wang, B. W. Bogan, J.-Q. Ni, E. L. Cortus, A. J. Heber
}

\begin{abstract}
Air emissions from animal feeding operation (AFO) facilities have been of increasing concern. While the EPA was pressured to put more stringent regulations on the AFO industry, there was an absence of suitable emission data to support regulatory decisions for different AFOs due to limitations of past studies and the absence of standard measurement protocols that link an emission rate to the different activities responsible for the emissions. In 2005, the EPA announced the AFO Air Quality Compliance Agreement, under which a two-year National Air Emissions Monitoring Study (NAEMS) was initiated. The NAEMS Southeast Layer Site was designed to collect baseline air emissions from highrise tunnel-ventilated layer houses. The target emissions at this site were ammonia $\left(\mathrm{NH}_{3}\right)$, hydrogen sulfide $\left(\mathrm{H}_{2} \mathrm{~S}\right)$, carbon dioxide $\left(\mathrm{CO}_{2}\right)$, volatile organic compounds (VOCs), and particulate matter (PM), including $P M_{2.5}$, $P M_{10}$, and total suspended particulate (TSP). In addition, operational and environmental variables (e.g., animal activity, room temperature and relative humidity $(R H)$, house ventilation rate, ambient temperature and $R H$, wind speed and direction, and solar radiation) were monitored to address their impacts on the emissions. Information about house inventory and major farm management activities was also collected. This article documents site characteristics and monitoring methods for the NAEMS at the Southeast Layer Site. Baseline emissions of PM and gaseous pollutants, house ventilation rates, and apparent impacts of farm management activities are reported in parts II through VI of this series.
\end{abstract}

Keywords. Methodology, Monitoring, National Air Emissions Monitoring Study, Southeast Layer Site.

I $\mathrm{n}$ recent years, air emissions from animal feeding operations (AFOs) have become a serious political and environmental problem according to the U.S. Environmental Protection Agency (EPA) (EPA, 2004a, 2005). While the EPA and state regulatory agencies were pressured to regulate $\mathrm{AFO}$ air emissions under the Clean Air Act (CAA), the Comprehensive Environmental Response, Compensation, and Liability Act (CERCLA), and the Emergency Planning and Community Right-toKnow Act (EPCRA), there was an absence of suitable

Submitted for review in December 2011 as manuscript number SE 9570; approved for publication by the Structures \& Environment Division of ASABE in April 2013.

The authors are Lingjuan Wang-Li, ASABE Member, Associate Professor, Department of Biological and Agricultural Engineering, North Carolina State University, Raleigh, North Carolina; Qian-Feng Li, ASABE Member, Research Associate, Departments of Animal Science and Biosystems and Agriculture Engineering, Michigan State University, East Lansing, Michigan; Kaiying Wang, ASABE Member, Associate Professor, College of Biosystems Engineering and Food Science, Zhejiang University, Hangzhou, China; Bill W. Bogan, Operations Manager, Agricultural Research Programs, and Ji-Qin Ni, ASABE Member, Assistant Professor, Department of Agricultural and Biological Engineering, Purdue University, West Lafayette, Indiana; Erin L. Cortus, ASABE Member, Assistant Professor, Department of Agricultural and Biosystems Engineering, South Dakota State University, Brookings, South Dakota; Albert J. Heber, ASABE Member, Professor, Department of Agricultural and Biological Engineering, Purdue University, West Lafayette, Indiana. Corresponding author: Lingjuan Wang-Li, 186 Weaver Labs, Campus Box 7625, North Carolina State University, Raleigh, NC 27695-7625; phone: 919-515-6762; e-mail: Lwang5 @) ncsu.edu. emission data to support regulatory decisions for different AFOs due to limitations of past studies and the absence of standard measurement protocols that link an emission rate to the different activities responsible for the emissions (EPA, 2001, 2004b; NRC, 2003). In current regulatory practice, the EPA uses relatively simplistic emission factors to estimate air emissions (EPA, 1995). However, the currently available emission factors for AFOs were developed from inadequate datasets and inconsistent measurement protocols and methods. The emission factors were based on only the size and type of the AFO, with insufficient representation of different operational and management practices, housing types, and geographic locations (NRC, 2003).

Quantifying emissions from AFOs is a very complex process since so many factors are involved in their generation and dispersion. Generating reasonably accurate estimates of emissions from AFOs is difficult because of the complex interactions between animal characteristics and environmental conditions that affect emissions (NRC, 2003). Thus, the emission rates reported in the literature were inadequate to characterize all the major variables that affect emissions. Furthermore, accurate estimates of air emissions from individual AFOs require defined relationships between air emissions and various influencing factors (NRC, 2003).

Realizing the potentially significant impacts of AFO air emissions on public health, and the lack of scientific data to regulate the AFO industry (NRC, 2003), the livestock 
commodity groups and the EPA worked closely together for possible solutions. The outcome of this working relationship was the EPA AFO Air Quality Compliance Agreement (EPA, 2005), under which the AFO industry funded and provided full access to a number of representative farms for the National Air Emissions Monitoring Study (NAEMS) (Heber et al., 2008a, 2008b). Under the NAEMS, particulate matter (PM) (i.e., $\mathrm{PM}_{2.5}$, $\mathrm{PM}_{10}$, and total suspended particulate (TSP)), ammonia $\left(\mathrm{NH}_{3}\right)$, hydrogen sulfide $\left(\mathrm{H}_{2} \mathrm{~S}\right)$, carbon dioxide $\left(\mathrm{CO}_{2}\right)$, and volatile organic compounds (VOCs) were monitored at AFO production houses for two years on a $24 / 7$ basis.

The purpose of the NAEMS was to collect baseline air emission data that would help the EPA determine compliance status of AFOs. In addition, the NAEMS promoted a national consensus on air emission monitoring methods and procedures (Heber et al., 2008a). Fourteen AFO barn sites across the country were selected and approved by the EPA for animal housing emission studies. Among these 14 sites, one egg production farm in North Carolina was selected to represent air emissions from egg farms in the southeast region of the U.S. The specific objective of the NAEMS at the Southeast Layer Site (also known as the NC2B site) was to capture baseline emissions of air pollutants from two tunnel-ventilated high-rise layer houses. In addition, operational and environmental variables (e.g., animal activity, house temperature and relative humidity $(\mathrm{RH})$, house ventilation rate, ambient temperature and $\mathrm{RH}$, wind speed and direction, and solar radiation) were monitored to address their impacts on the emissions. This article reports the site specifics and the detailed monitoring methodology for two years of air emission data collection at the Southeast Layer Site. Results of the baseline emissions of PM and gaseous pollutants, ventilation, and impacts of the farm management activities are reported in parts II through IV of this series (Li et al., 2013a, 2013b; Wang-Li et al., 2013).

\section{The Monitored Site}

\section{THE EGg FARM}

The NC2B site was on a commercial egg production farm. The egg production operation at the farm consisted of nine egg layer houses, one egg processing (packing) plant, two wastewater treatment lagoons with solid traps, and a wastewater spray field (fig. 1). Among the nine buildings housing caged layers, houses 1 through 4 were tunnelventilated high-rise units, houses 5 and 6 were crossventilated high-rise buildings, and houses 93, 102, and 103 were naturally ventilated and had shallow pits.

In the high-rise houses, laying hens were placed in six (houses 1 through 4) or eight (houses 5 and 6) rows of 4tier curtain-backed cages in the upper floor (referred to as layer room) with $400 \mathrm{~cm}^{2} \mathrm{hen}^{-1}$ to comply with voluntary welfare guidelines (UEP, 2010). Manure fell onto the sloped curtains and then down into the pit (referred to as the manure pit), where it was stored for approximately 12 months. Solid manure was removed from the pit annually and transported to an organic farm for land application. Houses 1 through 4 were $18 \mathrm{~m}$ wide and $175 \mathrm{~m}$ long, with capacities of 103,000 hens each, whereas houses 5 and 6 were $21 \mathrm{~m}$ wide and $175 \mathrm{~m}$ long, each with a capacity of 132,000 hens. The houses were $15.2 \mathrm{~m}$ apart.

In the shallow-pit houses, laying hens were placed in five rows of 3-tier (house 93) or 4-tier (houses 102 and 103) curtain-backed cages. Manure fell onto the curtain backs and then down onto the concrete floor, from which it was flushed out twice daily to waste treatment lagoon systems (solid trap plus lagoon). Houses 102 and 103 were $18 \mathrm{~m}$ wide and $152 \mathrm{~m}$ long, with capacities of 75,000 hens per house, whereas house 93 was $18 \mathrm{~m}$ wide and $107 \mathrm{~m}$ long and each housed 30,000 hens. The houses were also $15.2 \mathrm{~m}$ apart.

As a commitment to protect the environment, the facility established a comprehensive "environmental management system" and was in compliance with ISO 14000 standards.

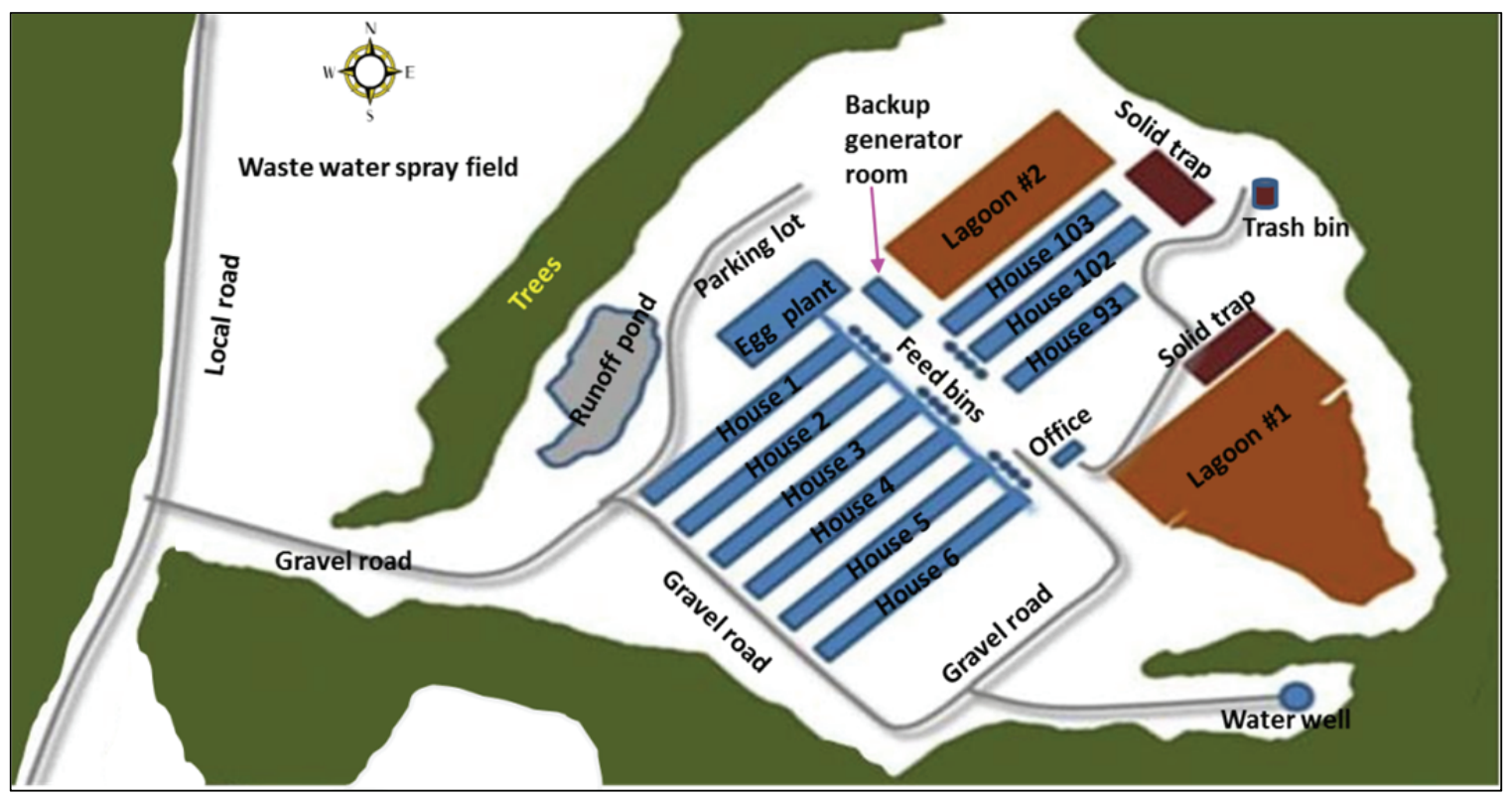

Figure 1. Layout of the NC2B egg production facility. 


\section{The Monitored Housing SySTEM}

Among the nine egg production houses, two tunnelventilated houses (3 and 4) were monitored for baseline emissions of target pollutants under the NAEMS. These two houses were constructed in 2002-2003. Each house had a ridge height of $8.4 \mathrm{~m}$, side wall height of $5.5 \mathrm{~m}$, and manure pit height of $2.7 \mathrm{~m}$.

Each endwall (east or west) of the houses was equipped with seventeen $122 \mathrm{~cm}$ diameter, 480 VAC, three-phase, belt-driven, single-speed ventilation fans (model 382644822, Chore-Time, Milford, Ind.). Among these 17 fans, eight were located in the layer room, and nine were in the manure pit (fig. 2). Each house had 34 fans in total and was ventilated in 11 stages. Two stage-1 fans were located in the middle of each endwall (fans 13 and 30 on east and west endwalls, respectively) in the manure pit. These two stage-1 fans were also referred to as the primary representative exhaust fans (PREFs).

During warm weather, ventilation air entered the layer room through $36.5 \mathrm{~m}$ long air inlet curtains centered on the north and south sidewalls of the house. During cold or mild weather, ventilation air was drawn into the attic through the eave inlets and then into the layer room through two houselength ceiling baffles. The sidewall inlet curtains and the ceiling baffles were automatically controlled by the farm's building environmental control system (BECS) (Poultry Management Systems, Saranac, Mich.) based on the inhouse temperature and the house static pressure. No supplemental cooling or heating was used in any of the houses. Two generator sets provided emergency backup electric power for houses 1 through 6 .

The BECS used eight temperature sensors and one differential static pressure sensor to continuously monitor in-house temperature and static pressure for guiding ventilation control. In addition, each of the ventilation fans was equipped with a sensor to monitor fan rotational speed in revolutions per minute (rpm). The fan speeds were monitored by the farm house manager through the BECS. When a significant reduction in fan speed (approximately 5\%) was observed, the BECS issued a warning, and maintenance workers were dispatched to either adjust or replace the belt.

\section{Housing Management Practices}

Laying hen genetics were W-36 (Hy-Line International, West Des Moines, Iowa). The corn/soy-based feed formula varied with hen age according to standard commercial practices. Each of the houses held approximately 95,000 laying hens. Flocks were placed in the houses at around 18 weeks of age and were molted when they were about 60 weeks old. The molting process consisted of $5 \mathrm{~d}$ of premolting during which the hens were fed a high-calcium diet, $15 \mathrm{~d}$ of fasting when they were fed once daily at $45.4 \mathrm{~g} \mathrm{hen}^{-1}$, and the final $5 \mathrm{~d}$ when the flocks were fed once daily with the "returning" diet. Hens were sold at an age of approximately 110 weeks. During a production cycle, $0.1 \%$ of the hens in each house were weighed once every four weeks for statistically assessing overall average hen weight. Eggs were removed from each tier on belt conveyors, where they were counted, and then onto a single cross conveyor that transported the eggs to the packing plant at the east end of the facility. Daily egg production and water consumption were automatically recorded by the BECS as well as daily feed consumption, which was monitored by load cells under the feed bins. Daily mortalities were manually removed and recorded. The lighting program and feed delivery schedule were automatically controlled by the BECS.

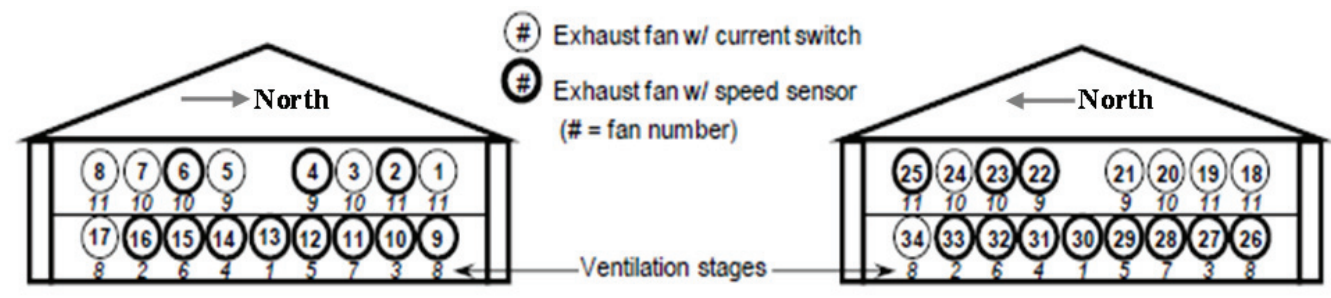

East end of each house

West end of each house

\begin{tabular}{|c|c|c|}
\hline Stage & Quntity & Fan Nuber \\
\hline 1 & 2 & 13,30 \\
\hline 2 & 2 & 16,33 \\
\hline 3 & 2 & 10,27 \\
\hline 4 & 2 & 14,31 \\
\hline 5 & 2 & 12,29 \\
\hline 6 & 2 & 15,32 \\
\hline 7 & 2 & 11,28 \\
\hline 8 & 4 & $9,17,26,34$ \\
\hline 9 & 4 & $4,5,21,22$ \\
\hline 10 & 6 & $3,6,7,20,23,24$ \\
\hline 11 & 6 & $1,2,8,18,19,25$ \\
\hline
\end{tabular}

Figure 2. Ventilation fan numbers and stage settings for the tunnel-ventilated houses. 
The major management activities are listed in table 1. The first flock in house 3 had already been molted and in its second lay cycle prior to the study and ranged in age from 575 to $769 \mathrm{~d}$. The second flock in house 3 was placed at $137 \mathrm{~d}$ and was $624 \mathrm{~d}$ old at the end of the study. The second flock was molted in April 2009. The first flock in house 4 had already been molted and was monitored from 540 to $792 \mathrm{~d}$ of age. The second flock in house 4 ranged from 129 to 588 d and was replaced in September 2009 after one lay cycle. The third and final flock observed by the study in house 4 arrived at $129 \mathrm{~d}$ and was $192 \mathrm{~d}$ old when monitoring was discontinued. There were three manure cleanout events in each house. A $14.5 \mathrm{~min}$ long feed delivery event occurred every $2 \mathrm{~h}$ from 2:00 to 20:00 in each house as feed was conveyed to the hens with an auger system. The houses were cleaned twice weekly. The cleaning activities included regularly blowing dust off the fans with compressed air and sometimes cleaning the ceiling.

The manure pits of both houses were emptied completely once during the first flock and twice during the second flock (table 1). The common practice of the producer was to clean out the solid manure from the manure pits annually; however, due to the producer's decision to move the manure load-out from spring to summer, an additional cleanout event occurred in July 2009. Table 2 summarizes the total quantities of manure moved out of the two houses during the three cleanout events.

Table 1. Schedule of major house management activities.

\begin{tabular}{ccc}
\hline Event & House 3 & House 4 \\
\hline $\begin{array}{c}\text { Layer room } \\
\text { lighting }\end{array}$ & $\begin{array}{c}\text { Lights were on from 3:00 to 20:00 } \\
\text { and off from 20:00 to 3:00 }\end{array}$ \\
\hline Feed delivery & Feed delivered every 2 h from 2:00 to 20:00 \\
\hline House cleaning & \multicolumn{2}{c}{ Twice weekly } \\
\hline $\begin{array}{c}\text { Removal of } \\
\text { spent hens }\end{array}$ & 6-9 April 2008 & 3-4 June 2008 \\
\hline Flock 1 removal & 6-9 April 2008 & 3-4 June 2008 \\
\hline $\begin{array}{c}\text { House empty } \\
\text { (unoccupied) }\end{array}$ & 10-27 April 2008 & 5-17 June 2008 \\
\hline Flock 2 placement & 28-30 April 2008 & 18-24 June 2008 \\
\hline Hen molting & 5 April to 3 May 2009 & - \\
\hline Flock 2 removal & - & 28-30 Sept. 2009 \\
\hline $\begin{array}{c}\text { House empty } \\
\text { (unoccupied) }\end{array}$ & - & 1-25 Oct. 2009 \\
\hline Flock 3 placement & - & 26-28 Oct. 2009 \\
\hline Manure cleanouts & $\begin{array}{c}\text { 12-19 March 2008, } \\
\text { 24-27 March 2009, } \\
\text { and 21-25 July 2009 }\end{array}$ & $\begin{array}{c}\text { 23-27 March 2008, } \\
\text { and 21-25 July 2009, }\end{array}$ \\
\hline
\end{tabular}

Table 2. Total amount of manure removed from houses 3 and 4 during the three cleanout events. ${ }^{[a]}$

\begin{tabular}{cccccc}
\hline & \multicolumn{2}{c}{ House 3 } & & \multicolumn{2}{c}{ House 4 } \\
\cline { 2 - 3 } \cline { 5 - 6 } Date & $\begin{array}{c}\text { Loads } \\
(n)\end{array}$ & $\begin{array}{c}\text { Wt Load } \\
(\mathrm{kg})\end{array}$ & & $\begin{array}{c}\text { Loads } \\
(n)\end{array}$ & $\begin{array}{c}\text { Wt Load } \\
(\mathrm{kg})\end{array}$ \\
\hline March 2008 & 39 & 22,226 & & 36 & 22,226 \\
March 2009 & 42 & 19,505 & & 47 & 19,505 \\
July 2009 & 18 & 17,418 & & 23 & 17,418 \\
\hline
\end{tabular}

[a] There were 1.5 loads remaining in each house to keep floors dry and insect population low.
Monitoring ANd SAMPling Methods

MoNitoring Site SETUP AND MoNitoring SYSTEM

The NC2B site setup began on 21 May 2007 and was completed on 23 September 2007. The four-month site setup activity was conducted following the EPA-approved quality assurance project plan (QAPP) (Heber et al., 2008b), which included a detailed site monitoring plan and a complete set of standard operating procedures. Valid data collection was conducted from 24 September 2007 to 31 December 2009.

The air sampling and monitoring system was centered around an on-farm instrument shelter (OFIS) (figs. 3 and 4). The OFIS was located between houses 3 and 4 at the east ends of the houses to minimize distances to sampling points and sensors. Raceways (10 $\mathrm{cm}$ dia. PVC pipe) housed the air sampling tubing and cables that ran from various sampling and data collection points to the OFIS. The raceways were heated to avoid condensation in the air sampling tubes. The temperatures in the two raceways were continuously monitored and controlled. Due to frequent lightning storms in the area, additional electrical grounding to earth was installed at the OFIS and the weather tower to protect sensors and instruments.

For gaseous pollutant measurements, air samples were sequentially drawn from seven gas sampling locations (GSLs) through Teflon tubing to the sampling manifold of a custom-built gas sampling system (GSS) and then to different gas analyzers via the GSS analyzer manifold. Among the seven GSLs, three gas sampling probes were installed in each house (figs. 3 and 4) and one sampling probe was located outside at the tunnel ventilation air inlet of house 3 (fig. 4). Detailed descriptions of the sampling probe locations are included in table 3 .

For PM measurements, concentrations at the exhaust outlets of the two houses were monitored according to two different strategies. Strategy 1 (24 Sept. 2007 to 26 Feb. 2009) consisted of one TEOM PM monitor (table 4) located $2 \mathrm{~m}$ upstream of the minimum ventilation fan (manure pit, middle of the east end) in each house to simultaneously measure PM concentrations (figs. 4 and 5, table 3). In strategy 2 (5 Mar. 2009 to 26 Oct. 2009), the TEOM in house 3 was relocated immediately upstream of fan 4 (layer room, middle of the east end) in house 4 (not shown in figs. 3 and 4). In this strategy, a TEOM in the manure pit and the layer room of house 4 simultaneously measured exhaust PM concentrations to account for differences between the manure pit and layer room. The PM of the inlet air was measured using a beta gauge PM monitor (figs. 3 and 4). Concentrations of $\mathrm{PM}_{2.5}$ were simultaneously measured at the three monitoring locations for 6 to 19 d in January-February 2008, October 2008, and July-August 2009. Concentrations of TSP were simultaneously measured at all three locations for nine 5 to $16 \mathrm{~d}$ periods, and $\mathrm{PM}_{10}$ was simultaneously measured at three locations at all other times. All three PM monitors were always equipped with the same inlet type.

Ventilation fan status was monitored using either fan speed sensors or current switches (fig. 2). Although each ventilation fan was already equipped with a fan speed 


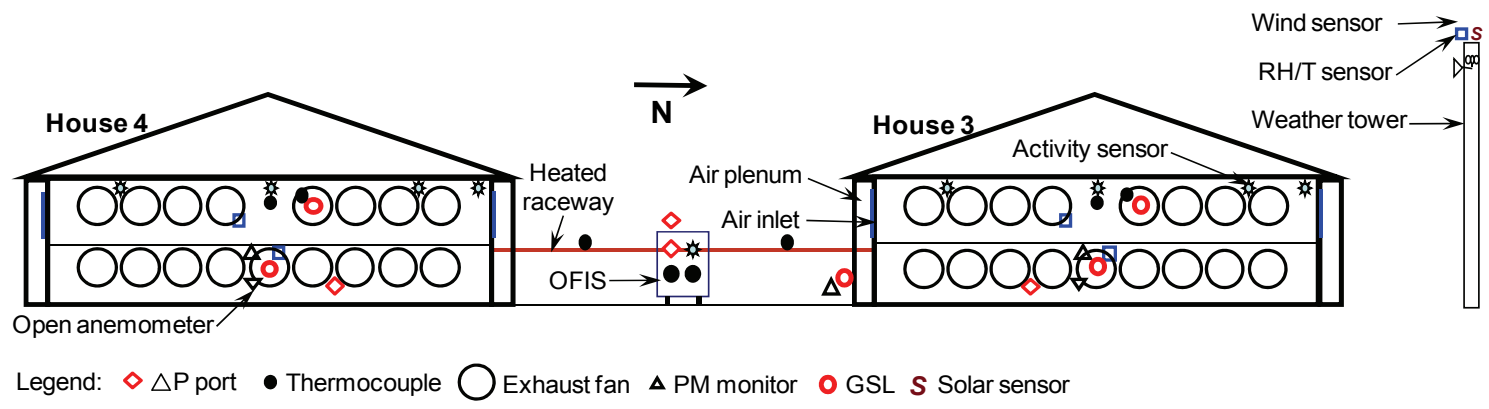

Figure 3. End view of the sensor locations and gas sampling locations (GSL).

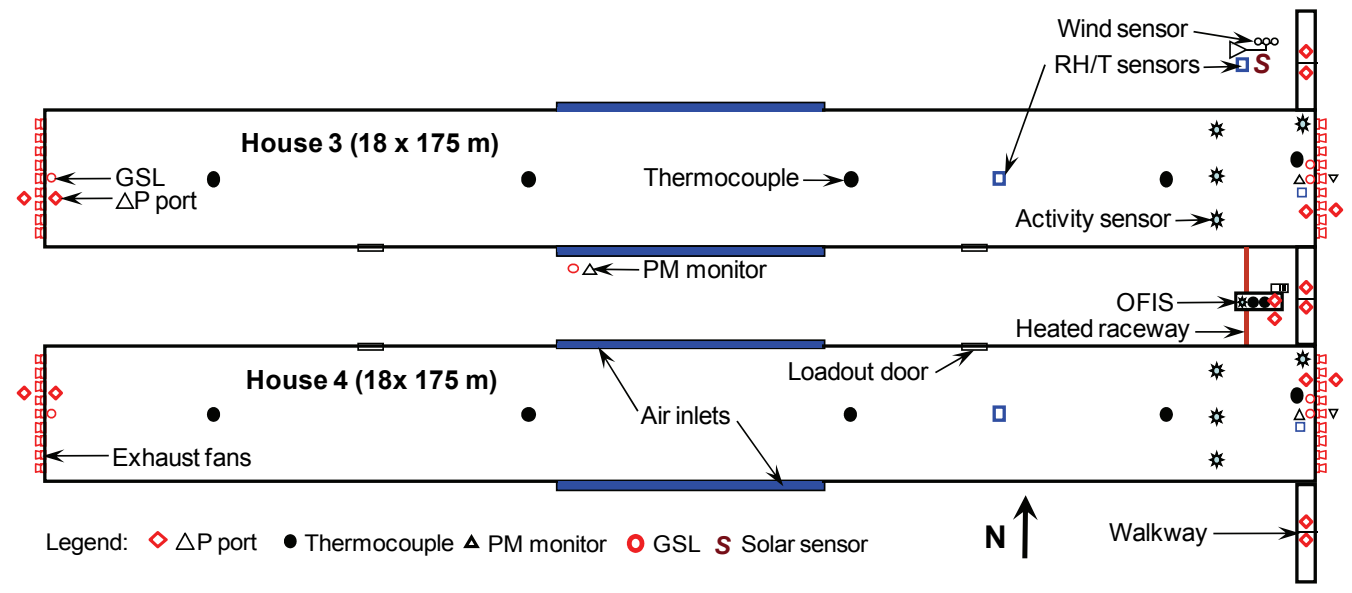

Figure 4. Top view of the sensor and gas sampling locations (GSL).

Table 3. Air sampling and monitoring locations in houses 3 and 4.

\begin{tabular}{|c|c|c|}
\hline Pollutants & Sampling Location ${ }^{[a]}$ & Qty. \\
\hline \multirow[t]{3}{*}{$\begin{array}{l}\mathrm{NH}_{3}, \mathrm{H}_{2} \mathrm{~S} \\
\text { and } \mathrm{CO}_{2}\end{array}$} & $\begin{array}{l}\text { Fans } 13 \text { and } 30 \text { on east and west endwalls } \\
\text { (manure pit); }\end{array}$ & 2 \\
\hline & Fan 4 on east endwall (layer room); & 1 \\
\hline & $\begin{array}{l}\text { Inlet: } 2 \mathrm{~m} \text { from south wall of house } 3 \text {, and } 2 \mathrm{~m} \\
\text { from west end of the air inlet (outside) }\end{array}$ & 1 \\
\hline $\mathrm{PM}_{2.5}, \mathrm{PM}_{10}$, & Fan 13 on east end, beneath egg conveyor belt; & 1 \\
\hline and TSP & $\begin{array}{l}\text { Inlet: } 2 \mathrm{~m} \text { from south wall of house } 3 \text {, and } 2 \mathrm{~m} \\
\text { from west end wall (outside) }\end{array}$ & 1 \\
\hline
\end{tabular}

sensor for the farm's BECS, the farm's fan speed sensors could not be interfaced to the NAEMS data acquisition and control (DAC) system. Consequently, a second speed sensor was installed on 22 representative ventilation fans to continuously monitor fan speeds.

In addition to pollutant concentration measurements, environmental variables that directly or indirectly influenced emissions were also monitored at various locations (figs. 3 and 4). These variables included animal and worker activity, temperature, RH, atmospheric pressure, and weather conditions (wind speed and direction, air temperature and $\mathrm{RH}$, and solar radiation). The atmospheric pressure was measured inside the OFIS by the TEOM controller unit, which contained an integrated pressure sensor (model MPX4250A, Motorola, Schaumberg, Ill.). The weather data were measured using a $10 \mathrm{~m}$ weather tower situated between houses 2 and 3 near the east end of the houses with all the sensors $1.5 \mathrm{~m}$ above the building ridges. Five extra electrical grounding rods were installed to protect the sensors on the tower from the effects of lightning.

\section{MEASURED VARIABLES AND INSTRUMENTATION}

The continuous measurement variables and the instruments used to take the measurements are listed in tables 4 and 5. The switching of the seven GSLs was controlled by a 16-channel digital output module of the DAC. Initially, an air sample at each of the six in-house sampling points (locations) was taken for $10 \mathrm{~min}$, and air samples at the house 3 ventilation inlet were taken at least twice daily, with 20 min sampling duration. An experiment was conducted after three months of valid data collection to determine whether concentration equilibrium was obtained within the 10 or $20 \mathrm{~min}$ period. It was observed that $10 \mathrm{~min}$ was sufficient for the six in-house exhaust GSLs, but $30 \mathrm{~min}$ was required for the GSL at the house ventilation inlet to reach equilibrium. Consequently, the sampling duration for this GSL was increased to $30 \mathrm{~min}$ on 28 January 2008.

The signals (analog or digital) of 144 variables measured by various sensors and analyzers were continuously sent to an on-site computer system (OSCS) in the OFIS for data display, computing, and recording ( $\mathrm{Ni}$ and Heber, 2010). The OSCS consisted of customdeveloped computer software (AirDAC), a set of DAC hardware, and a computer. FieldPoint (FP) modules and universal serial bus (USB) devices (National Instruments, 
Table 4. Measurement variables and equipment.

\begin{tabular}{|c|c|c|}
\hline Measured Variables & Equipment or Sensor & Manufacturer \\
\hline Wind speed and direction & Wind Sentry model 03002VM anemometer & R.M. Young Co., Traverse City, Mich. \\
\hline Atmospheric pressure & Model MPX4250A integrated pressure sensor & Motorola Solutions, Schaumberg, Ill. \\
\hline Solar radiation & Model LI-200SL pyranometer & LI-COR, Lincoln, Neb. \\
\hline Outside air $\mathrm{T} / \mathrm{RH}$ & Model RHT-WM capacitance RH/T & Novus Automation, Porto Alegre, Brazil \\
\hline $\begin{array}{l}\text { Sampling probe air and cage air } \\
\text { temperatures and } \mathrm{RH}\end{array}$ & Capacitance-type RH/T probe (RHT-WM) & Novus Automation, Porto Alegre, Brazil \\
\hline $\begin{array}{l}\text { Inside air and raceway air } \\
\text { temperatures }\end{array}$ & Type-T thermocouples & TE Wire and Cable, Saddle Brook, N.J. \\
\hline Animal and worker activity & PIR model VS-SRN2000 infrared motion sensor & Visonic, Bloomfield, Conn. \\
\hline Fan on/off status & CR9380-NPN current switch & CR Magnetics, St. Louis, Mo. \\
\hline Fan rotational speed & MP100701 Hall-effect proximity sensor & Cherry Electrical Products, Pleasant Prairie, Wisc. \\
\hline Fan static pressure & Model 260 differential static pressure sensor & Setra Systems, Boxborough, Mass. \\
\hline Calibration gas dilution & Model 4040 six-port gas diluter & Environics, Tolland, Conn. \\
\hline $\mathrm{CO}_{2}$ and $\mathrm{NH}_{3}$ concentrations & Innova 1412 multi-gas analyzer & LumaSense Technologies A/S, Ballerup, Denmark \\
\hline $\mathrm{H}_{2} \mathrm{~S}$ concentration & TEI 450i $\mathrm{H}_{2} \mathrm{~S}$ analyzer & Thermo Fisher Scientific, Waltham, Mass. \\
\hline PM concentration (inlet air) & Beta gauge FH62C-14 PM monitor & Thermo Fisher Scientific, Franklin, Mass. \\
\hline PM concentration (in-house) & TEOM 1400a PM monitor & Thermo Fisher Scientific, Waltham, Mass. \\
\hline
\end{tabular}
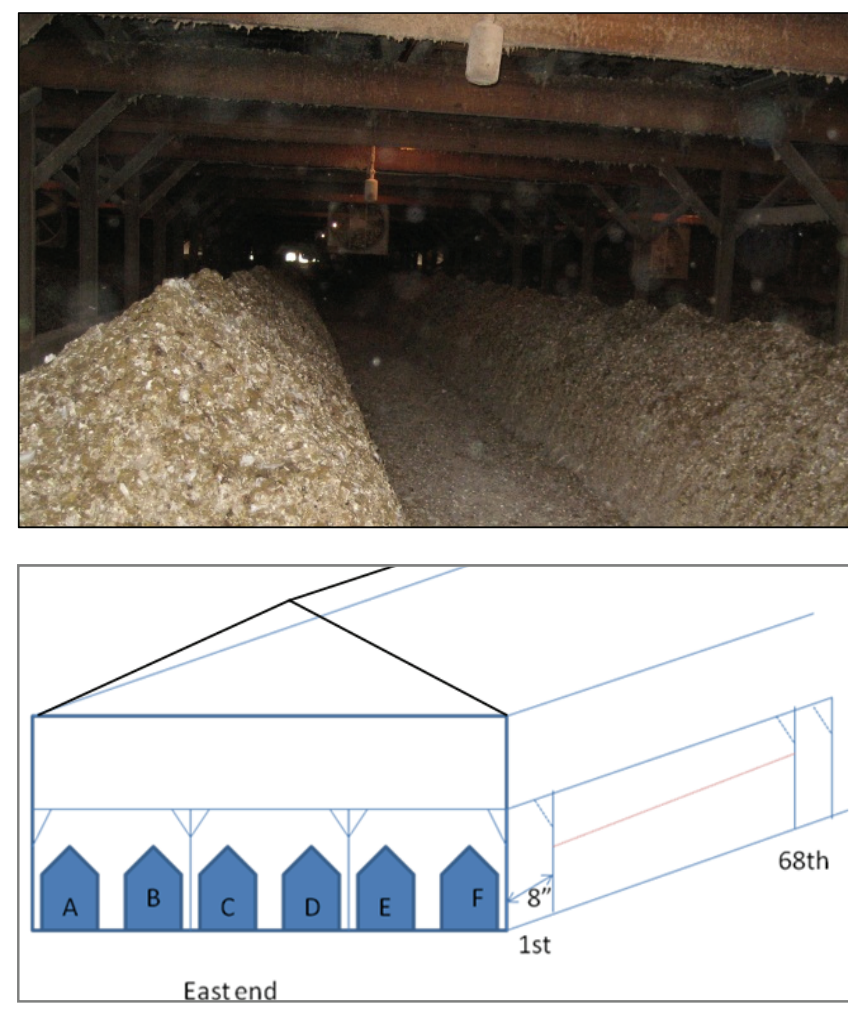

Figure 5. (top) Manure piles and (bottom) surface sampling section.

Table 5. List of data acquisition hardware and configuration.

\begin{tabular}{ccccc}
\hline $\begin{array}{c}\text { Manufacturer } \\
\text { and Model }{ }^{[\mathrm{a}]}\end{array}$ & $\begin{array}{c}\text { I/O } \\
\text { Type }\end{array}$ & $\begin{array}{c}\text { No. of } \\
\text { Units }\end{array}$ & $\begin{array}{c}\text { Channels } \\
\text { per Unit }\end{array}$ & Notes \\
\hline $\begin{array}{c}\text { NI } \\
\text { FP-AI-112 }\end{array}$ & $\begin{array}{c}\text { Analog } \\
\text { input }\end{array}$ & 4 & 16 & $\begin{array}{c}\text { Single-ended, } \\
\text { 16-bit }\end{array}$ \\
\hline $\begin{array}{c}\text { NI } \\
\text { FP-TC-120 }\end{array}$ & $\begin{array}{c}\text { Thermo- } \\
\text { couple }\end{array}$ & 2 & 8 & \\
\hline $\begin{array}{c}\text { NI } \\
\text { FP-DO-401 }\end{array}$ & $\begin{array}{c}\text { Digital } \\
\text { output }\end{array}$ & 1 & 16 & $\begin{array}{c}\text { 2 A at 10-30 } \\
\text { VDC }\end{array}$ \\
\hline MCC & $\begin{array}{c}\text { Counter } \\
\text { input }\end{array}$ & 5 & 10 & \\
USB 4303 counter & $\begin{array}{c}\text { Digital } \\
\text { input }\end{array}$ & 1 & 96 & \\
USB DIO 96H & NI = National Instruments, Austin, Tex.; MCC = Measurement \\
Computing Corporation, Norton, Mass.
\end{tabular}

Table 6. Summary of fan testing events for the two monitored houses (total number of fans $=68$ ).

\begin{tabular}{ccccc}
\hline Static & $\begin{array}{c}\text { No. of } \\
\text { Fans }\end{array}$ & $\begin{array}{c}\text { Percent } \\
\text { Tested }\end{array}$ & $\begin{array}{c}\text { Avg. No. } \\
\text { of Runs } \\
\text { per Fan }\end{array}$ \\
\hline 13-21 Nov. 2007 & As found & 68 & $100 \%$ & 3 \\
9-13 June 2008 & As found & 45 & $66.2 \%$ & 3 \\
15-17 July 2009 & As found & 67 & $98.5 \%$ & 3 \\
28 July 2009 & Adjusted $^{[a]}$ & 3 & $4.4 \%$ & 9
\end{tabular}

a] Fans were tested at three house static pressures (adjusted using the ventilation inlets) to determine in-field fan performance as compared with fan curves based on independent testing and published by the manufacturer.

Austin, Tex.; Measurement Computing, Norton, Mass.) were selected and configured for analog, digital, thermocouple, and counter inputs; and digital outputs. Serial communication (RS-232) was used to acquire data from the multi-gas analyzer and a gas diluter (model S-4040, Environics, Tolland, Conn.) for analyzer calibration. The OSCS also controlled sequential switching of multiple GSLs and the raceway heating system.

\section{IN SITU FANS AIRFLOW TESTS}

For building ventilation rate determination, in addition to continuous monitoring of the fans' on/off status or fan rotational speed and the static pressure, in situ airflow measurements were also conducted using a field-portable Fan Assessment Numeration System (FANS) (Gates et al., 2004). The FANS (model 38264-4822, University of Kentucky, Lexington, Ky.) was calibrated at the Bioenvironmental and Structural Systems (BESS) Laboratory at the University of Illinois at Urbana-Champaign in June 2007 and March 2009. The airflows of 3 to 68 fans were measured with the FANS during each of four in situ measurement events (table 6).

\section{MANURE SAMPLING}

Manure samples were collected for analysis of several manure characteristics to facilitate the calculations of a nitrogen balance for each house and to characterize this important gas emission source. Two types of manure 


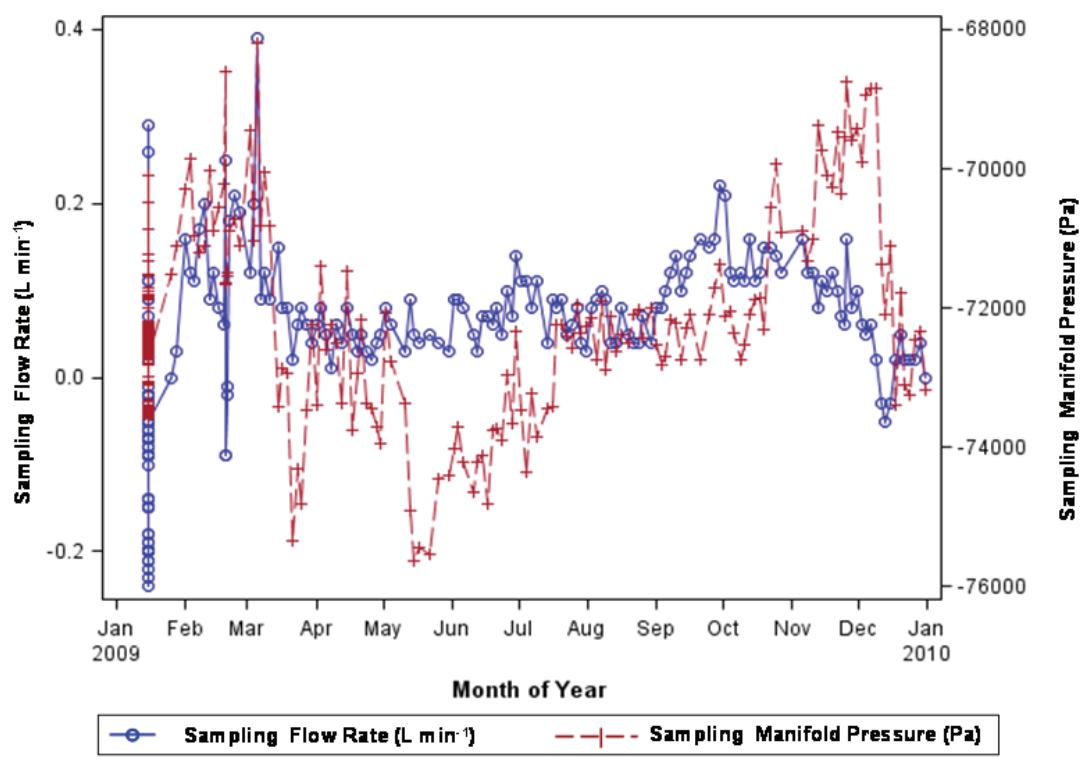

Figure 6. Automatic GSS leak testing results (sampling airflow $<0.45 \mathrm{~L} \mathrm{~min}^{-1}$ indicates leak-free status).

samples were taken from each house: surface manure samples (fresh manure), and load-out manure samples. Surface manure samples were taken from the top of each manure pile and analyzed for moisture content, $\mathrm{pH}$, and total ammoniacal nitrogen (TAN). Load-out manure samples were taken from manure bulk when it was removed from the houses and were analyzed for total Kjeldahl nitrogen (TKN), nitrate-nitrogen $\left(\mathrm{NO}_{3}-\mathrm{N}\right)$, and moisture content.

In each house, there was a $166 \mathrm{~m}$ long manure pile in the pit under each of six rows of cages on the second floor. The distances between the ends of the manure piles and the end walls of the pit were about $4.9 \mathrm{~m}$. The pile cross-sections were approximately pentagonal, and the cross-sectional area increased as manure accumulated.

For the surface manure sampling, a block random sampling design was used to obtain representative samples. This sampling procedure included the following steps:

1. Divided each manure pile into sixty-eight $2.4 \mathrm{~m}$ long sections (fig. 6).

2. Designed a $6 \times 68$ spreadsheet and used a random number function to randomly select 40 of the 408 sections in each house for each sampling event.

3. Collected 40 samples of about equal mass from each randomly chosen section.

4. Combined and mixed the 40 samples into one large container for each house.

5. Collected subsamples (about $0.5 \mathrm{~kg}$ ) from the mixtures.

During loadout, as the manure was pushed from the house with a skid loader and loaded onto trucks, 12 random loadout manure samples per house were taken from either the truck or the loader.

All surface and loadout samples taken at each sampling event were packed on ice and transported immediately to a freezer to be frozen quickly on the same day. The frozen samples were shipped with gel ice to an independent laboratory (Midwest Laboratories, Omaha, Neb.) for analysis. A total of 164 surface and 44 loadout samples were collected (table 7).
Table 7. Record of manure sampling events at site NC2B.

\begin{tabular}{cccc}
\hline Sampling & Type of Manure & \multicolumn{2}{c}{ Number of Samples } \\
\cline { 3 - 4 } Date & Sample & House 3 & House 4 \\
\hline 16 Jan. 2008 & Surface & 15 & 15 \\
13 June 2008 & Surface & 12 & 12 \\
13 Nov. 2008 & Surface & 12 & 12 \\
18 Nov. 2008 & Surface & 36 & - \\
13 Mar. 2009 & Surface & 13 & 13 \\
13 Aug. 2009 & Surface & 24 & 24 \\
12 Mar. 2008 & Cleanout & 12 & 12 \\
24 Mar. 2009 & Cleanout & 5 & 5 \\
26 Mar. 2009 & Cleanout & 5 & 5 \\
\hline
\end{tabular}

\section{VOC SAMPLING}

The canister method was used to collect samples for determination of house emissions of total VOC. Four "whole air" samples were collected in stainless steel canisters, and the sampling period was $24 \mathrm{~h}$ for each sampling event.

Two canisters were placed in the manure pit of house 4 at the PREF (fan 13), where one TEOM sampler was located for PM monitoring. The other two canisters were placed near a stage-9 exhaust fan (fan 4) in the layer room of the east end of house 4 at the second TEOM, which had been moved to the layer room from house 3 . The canisters were secured onto the top of the TEOM enclosures, which were about $1.3 \mathrm{~m}$ above the floor.

Sampling of VOC was conducted in 2009 on April 12 and 27, May 20, July 2, August 26, and September 9 and 18 for $24 \mathrm{~h}$ each time. After sampling, the canisters were shipped to Purdue University for analysis with a GC-MS. The samples were shipped on the same day that sampling was completed, except for the sampling events on May 20 and August 26 when they were shipped the following day.

\section{House InVENTORY CHECKS}

Information about house inventory and hen age, weight, and mortality, feed and water consumption, and egg production is needed to determine normalized emission rates, to conduct mass balances for estimating air emissions, and to identify key factors for developing 
Table 8. Tests of GSS leakage and GSL performance audits (PA).

\begin{tabular}{|c|c|c|}
\hline Date $(\mathrm{m} / \mathrm{d} / \mathrm{y})$ & Test Type & Locations or Replications $(n)^{[\mathrm{a}]}$ \\
\hline $9 / 24 / 07$ & All sampling leak checks & All sampling locations \\
\hline $11 / 19 / 07$ & All sampling leak checks & All sampling locations \\
\hline $12 / 4 / 08$ & $80 \mathrm{ppm} \mathrm{NH}_{3} \mathrm{PA}$ & $\mathrm{H} 3 \mathrm{~F} 4, \mathrm{H} 4 \mathrm{~F} 4$, and $\mathrm{H} 3 \mathrm{~F} 30$ \\
\hline $1 / 9 / 09$ & GSS bypass-pump flow check & $n=8$ \\
\hline $1 / 9 / 09$ & H3F13 flow check ${ }^{[b]}$ & $n=9$ \\
\hline $1 / 15 / 09$ & Sampling leak checks & All sampling locations \\
\hline $1 / 29 / 09$ & $80 \mathrm{ppm} \mathrm{NH}_{3} \mathrm{PA}$ & H4F4, H4F13, H4F30, H3F30, inlet, H3F13, H3F4, and GSS top \\
\hline $2 / 6 / 09$ & $440 \mathrm{ppb} \mathrm{H}_{2} \mathrm{~S} \mathrm{PA}$ & GSS top, H3F4, H4F4, H3F13, H4F13, H3F30, H4F30, and inlet \\
\hline $8 / 17 / 09$ & $5000 \mathrm{ppm} \mathrm{CO}_{2} \mathrm{PA}$ & Directly into gas analyzers, H3F4, H3F13, H4F4, H4F13, H3F30, H4F30, and inlet \\
\hline $11 / 17 / 09$ & $80 \mathrm{ppm} \mathrm{NH}_{3} \mathrm{PA}$ & H3F $13, \mathrm{H} 4 \mathrm{~F} 13$ \\
\hline $11 / 24 / 09$ & $80 \mathrm{ppm} \mathrm{NH}_{3} \mathrm{PA}$ & H4F30, H3F30 \\
\hline $1 / 5 / 10$ & $80 \mathrm{ppm} \mathrm{NH}_{3} \mathrm{PA}$ & Directly into gas analyzers, H3F4, H4F4 \\
\hline
\end{tabular}

mitigation strategies. As a management practice, the farm's BECS automatically recorded daily house inventory data. The inventory data included house identification, reporting date, hen age, population, average body mass, mortality (total and percentage), house temperature (high, low, and average), egg production, water and feed consumption, and feed formulations.

Daily inventory data were collected from the producer during the weekly site visits, and checks of randomly selected cages in each house were conducted to verify hen counts in those cages. The hen counts agreed very well with the farm's inventory data for all checks. A scale verification and hen weight confirmation experiment was conducted. Two groups of 20 hens were randomly selected from houses 3 and 4 . These hens were weighed using the farm's scale and the research team's scale.

\section{QUALITY ASSURANCE AND QUALITY Control (QA/QC) \\ General Site MaInTenance}

Research personnel from North Carolina State University (NCSU) visited the site 336 times. At each site visit, various site maintenance and calibration activities were conducted according to the requirements of the QAPP.

\section{Gas Sampling System Performance Audits}

Prior to valid data collection, an initial test of the gas sampling system (GSS) was conducted to verify solenoid valve control response and communication with AirDAC. Two types of GSS leak tests were conducted. The first type examined GSS integrity by briefly creating a "dead head" against the pump by manually or automatically closing all solenoid valves, while measuring exhaust airflow with a portable rotameter (model RMA 150, Dwyer Instruments, Michigan City, Ind.) and recording the leakage flow with the GSS mass flowmeter. Automatic testing was conducted by AirDAC every three days, beginning in February 2009. The second type of leak test monitored GSS flow and pressure after manually setting AirDAC to sample from a particular GSL and plugging (with a cap) the GSL's gas sampling probe, which created a GSS manifold vacuum of about $-75,000 \mathrm{~Pa}$. Based on preliminary tests, GSS flows under dead-head conditions that were $10 \%$ or less $(<0.45 \mathrm{~L}$ $\left.\mathrm{min}^{-1}\right)$ of the normal GSS flow rate of $4.5 \mathrm{~L} \mathrm{~min}^{-1}$ indicated leak-free operation under normal GSS manifold vacuums of $-5,100$ to $-9,700 \mathrm{~Pa}$.

In addition to the two types of GSS leak tests, performance audits (PAs) were routinely conducted using $50 \mathrm{~L}$ Tedlar bags containing certified concentrations of $\mathrm{NH}_{3}, \mathrm{H}_{2} \mathrm{~S}$, or $\mathrm{CO}_{2}$ and connected to individual sampling lines. The tests were used to check for precision, response (equilibrium) time, and leakage in the sampling lines. The QAPP required the agreement of equilibrated concentrations and certified gas concentration to be within $10 \%$ for each PA. Table 8 summarizes the results of the GSS leak tests and GSL performance audits by sampling event.

\section{Gas Analyzer Noise Tests}

To assess the minimum detection limit (MDL) of the gas measurements, analyzer noise tests were conducted on the Innova $1412\left(\mathrm{NH}_{3}\right.$ and $\left.\mathrm{CO}_{2}\right)$ and $450 \mathrm{i}\left(\mathrm{SO}_{2}\right.$ and $\left.\mathrm{H}_{2} \mathrm{~S}\right)$. The analyzers measured zero air (Cat. No. AIO.OCE-T CEM zero-grade, Praxair, Indianapolis, Ind.) continuously for 30 to $50 \mathrm{~min}$ after equilibrium of the instrument readout was reached.

\section{Zero/SPan Checks ANd Multipoint \\ CALIBRATIONS OF ANALYZERS}

Weekly zero/span checks were conducted to monitor GSS and analyzer performance. Certified gases with known concentrations were introduced via the gas diluter through a challenge line. The challenge line was the GSL with its sampling probe located at fan 13 of house 3 (figs. 3 and 4). In this method, the calibration gases flowed through the same sampling system as actual house air samples did to reach the analyzers in the OFIS. During zero/span checks, analyzer responses were recorded to monitor changes in system performance over time. Span checks of $\mathrm{NH}_{3}$ prior to and after 9 September 2007 were conducted with 20 and $80 \mathrm{ppm}$ concentrations, respectively. A concentration of 40 ppm was used on 2 April 2009 and 20 October 2009. Span checks of $\mathrm{H}_{2} \mathrm{~S}$ were conducted with 220,440, 2000, or 4000 ppb concentrations.

For $\mathrm{NH}_{3}$, multipoint calibrations (MPCs) were conducted through the challenge line seven times using zero air and 20, 40, 60, and 80 ppm of $\mathrm{NH}_{3}$ (Cat. No. NIAM5MP-AS, Praxair Primary Standard).

For $\mathrm{H}_{2} \mathrm{~S}$, MPCs were conducted through the challenge line ten times using zero air and 220, 440, 2000, and 4000 
Table 9. Major maintenance events of the gas diluter.

\begin{tabular}{cl}
\hline Date $(\mathrm{m} / \mathrm{d} / \mathrm{y})$ & Events \\
\hline $8 / 16 / 07$ & Powered on \\
$11 / 21 / 07$ & Flow checked: multi-point calibration \\
$1 / 23 / 08$ & Checked connection \\
$5 / 19 / 08$ to $6 / 11 / 08$ & Annual calibration at Purdue University \\
$7 / 9 / 08$ & Updated data file \\
$1 / 15 / 09$ & Flow checked \\
$6 / 11 / 09$ to $7 / 9 / 09$ & Annual calibration at Purdue University \\
$1 / 8 / 10$ & Diluter was shut down \\
\hline
\end{tabular}

ppb concentrations (Cat. No. NI-HSR1E-AS, Praxair EPA Protocol Standard). Each MPC was conducted with replication.

\section{Gas Diluter Check}

The six-port gas diluter mentioned previously was used to generate precise gas calibration standards for single and multipoint calibrations of the gas analyzers (table 9). Two annual instrument calibrations were conducted on 19 May 2008 and 11 June 2009 at Purdue University. Flow rate checks and multipoint calibrations and checks were conducted on 21 November 2007 and 15 January 2009 using a reference flowmeter (MiniBuck model M-30, A.P. Buck, Orlando, Fla.).

\section{PM MONITOR CHECKS}

As a routine QA/QC practice, all the PM sampler heads $\left(\mathrm{PM}_{10}, \mathrm{PM}_{2.5}\right.$, or TSP) were thoroughly cleaned during each weekly site visit. Various maintenance and calibration activities were conducted on the TEOMs and beta gauge (table 10). Flow audits, leak checks, verification of mass constants $\left(K_{o}\right)$, and collocations of the TEOMs were conducted (table 10). Flow checks and mass verifications were conducted on the beta gauge (table 11).

\section{Calibrations and Audits of EnVironmental SENSORS}

The RH/T sensors for air temperature and $\mathrm{RH}$ measurements at various locations (figs. 3 and 4) were checked against spot measurements with a motorized psychrometer (table 12). All thermocouples (figs. 3 and 4) were checked using an ice or hot water bath and a thermometer on 28 August 2007, 16 October 2008, 7 January 2009, and 17 November 2009. Multipoint calibrations of the Setra 260 differential pressure sensors $(\Delta \mathrm{P}$, figs. 3 and 4 ) were conducted using an inclined stationary manometer (model D-2, Dwyer Instruments, Michigan City, Ind.) on 11 September 2007, 14 July 2008, and 7 September 2009. The atmospheric pressure sensor and the solar sensor were compared with that reported by a weather station located $30 \mathrm{~km}$ east of the site.

\section{Data Acquisition and Processing}

The intelligence of the project data acquisition and control system was implemented through AirDAC (Ni and Heber, 2010), which was written in LabVIEW (National Instruments, Austin, Tex.). AirDAC acquired signals every second from all on-line sensors and instruments and averaged them over 15 and $60 \mathrm{~s}$ intervals. The averaged
Table 10. Maintenance and calibration timeline for the exhaust air PM monitors.

\begin{tabular}{|c|c|c|}
\hline $\begin{array}{c}\text { Date } \\
(\mathrm{m} / \mathrm{d} / \mathrm{y})\end{array}$ & $\begin{array}{c}\text { TEOM } 1 \\
\text { (House 3) }\end{array}$ & $\begin{array}{c}\text { TEOM } 2 \\
\text { (House 4) }\end{array}$ \\
\hline $8 / 20 / 07$ & $\mathrm{PM}_{10}$ & $\mathrm{PM}_{10}$ \\
\hline $9 / 26 / 07$ & Leak test & Leak test \\
\hline $11 / 20 / 07$ & Leak/flow/temp & Leak/flow/temp \\
\hline $1 / 16 / 08$ & $\mathrm{PM}_{2.5}$ & $\mathrm{PM}_{2.5}$ \\
\hline $2 / 4 / 08$ & $\mathrm{PM}_{10}$ & $\mathrm{PM}_{10}$ \\
\hline $3 / 26 / 08$ & TSP & TSP \\
\hline $4 / 4 / 08$ & $\mathrm{PM}_{10}$ & $\mathrm{PM}_{10}$ \\
\hline $5 / 12 / 08$ & TSP & TSP \\
\hline $5 / 28 / 08$ & Flow check for $\mathrm{PM}_{10}$ & Flow check for. $\mathrm{PM}_{10}$ \\
\hline $7 / 18 / 08$ & Leak/flow/mass & Leak/flow/mass \\
\hline $8 / 7 / 08$ & TSP & TSP \\
\hline $8 / 21 / 08$ & $\mathrm{PM}_{10}$ & $\mathrm{PM}_{10}$ \\
\hline $10 / 17 / 08$ & Leak/flow/mass for TSP & Leak/flow/mass for TSP \\
\hline $10 / 23 / 08$ & $\mathrm{PM}_{10}$ & $\mathrm{PM}_{10}$ \\
\hline $10 / 24 / 08$ & $\mathrm{PM}_{2.5}$ & $\mathrm{PM}_{2.5}$ \\
\hline $10 / 30 / 08$ & $\mathrm{PM}_{10}$ & $\mathrm{PM}_{10}$ \\
\hline $11 / 26 / 08$ & Leak/flow check & Leak/flow check \\
\hline $1 / 9 / 09$ & TSP & TSP \\
\hline $1 / 15 / 09$ & $\mathrm{PM}_{10}$ & $\mathrm{PM}_{10}$ \\
\hline $1 / 23 / 09$ & Leak/flow/mass & Leak/flow/mass \\
\hline $2 / 26 / 09$ & & Collocation test: $\mathrm{PM}_{10}$ \\
\hline $2 / 27 / 09$ & & Collocation test: \\
\hline & & Leak/flow/mass for TSP \\
\hline $3 / 4 / 09$ & & $\mathrm{PM}_{10}$ \\
\hline $3 / 19 / 09$ & & $\mathrm{PM}_{10}$ \\
\hline $4 / 2 / 09$ & & TSP \\
\hline $4 / 10 / 09$ & & Leak: passed. $\mathrm{PM}_{10}$ \\
\hline $5 / 21 / 09$ & (TEOM I moved into & Leak/flow/mass \\
\hline $6 / 4 / 09$ & house 4 for collocation & TSP \\
\hline $6 / 11 / 09$ & test with IEUIM 2 , then & $\mathrm{PM}_{10}$ \\
\hline $7 / 24 / 09$ & moved to layer room.) & $\mathrm{PM}_{2.5}$ \\
\hline $8 / 6 / 09$ & & Leak/flow \\
\hline $8 / 7 / 09$ & & $\mathrm{PM}_{10}$ \\
\hline $8 / 20 / 09$ & & TSP \\
\hline $8 / 27 / 09$ & & $\mathrm{PM}_{10}$ \\
\hline $9 / 15 / 09$ & & Leak/flow/mass for TSP \\
\hline $9 / 22 / 09$ & & $\mathrm{PM}_{10}$ \\
\hline
\end{tabular}

Table 11. Checks and calibrations of the ambient PM monitor.

\begin{tabular}{ccc}
\hline $\begin{array}{c}\text { Date } \\
(\mathrm{m} / \mathrm{d} / \mathrm{y})\end{array}$ & Event & $\begin{array}{c}\text { Difference } \\
(\%)\end{array}$ \\
\hline $11 / 1 / 07$ & Mass verification & $<0.61 \%$ \\
$10 / 17 / 08$ & Flow check & $0.21 \%$ \\
$2 / 20 / 09$ & Flow check & $2.2 \%$ \\
$5 / 20 / 09$ & Mass verification & $1 \%(2607 \mu \mathrm{g}$ foil $)$ and \\
& & $9.9 \%(1309 \mu \mathrm{g}$ foil $)$ \\
$9 / 1 / 09$ & Mass verification & $0.61 \%$ \\
\hline
\end{tabular}

Table 12. Timeline for $\mathrm{RH} / \mathrm{T}$ sensor point checks.

\begin{tabular}{|c|c|c|}
\hline Sensor ID & Location $^{[\mathrm{a}]}$ & Dates $(\mathrm{m} / \mathrm{d} / \mathrm{y})$ \\
\hline H3F13 & House 3 fan 13 & $\begin{array}{l}9 / 18 / 07,10 / 16 / 08,9 / 1 / 09, \\
\text { and } 11 / 17 / 09\end{array}$ \\
\hline House 3 & $\begin{array}{l}\text { Empty cage at center } \\
\text { of house } 3\end{array}$ & $\begin{array}{l}\text { 9/18/07, 10/16/08, 9/1/09, } \\
\text { and } 11 / 17 / 09\end{array}$ \\
\hline H3F30 & $\begin{array}{l}\text { Gas sampling point } \\
\text { at house } 3 \text { fan } 30\end{array}$ & $\begin{array}{c}9 / 18 / 07,10 / 16 / 08,10 / 24 / 08 \\
9 / 1 / 09, \text { and } 11 / 17 / 09\end{array}$ \\
\hline H4F13 & $\begin{array}{l}\text { Gas sampling point } \\
\text { at house } 4 \text { fan } 13 \\
\end{array}$ & $\begin{array}{l}9 / 18 / 07,10 / 16 / 08,9 / 1 / 09, \\
\text { and } 11 / 17 / 09\end{array}$ \\
\hline House 4 & $\begin{array}{l}\text { Empty cage at center } \\
\text { of house } 4\end{array}$ & $\begin{array}{l}\text { 9/18/07, 10/16/08, 9/1/09, } \\
\text { and } 11 / 17 / 09\end{array}$ \\
\hline H4F30 & $\begin{array}{l}\text { Gas sampling point } \\
\text { at house } 4 \text { fan } 30\end{array}$ & $\begin{array}{c}9 / 18 / 07,10 / 16 / 08,10 / 24 / 08 \\
9 / 1 / 09, \text { and } 11 / 17 / 09\end{array}$ \\
\hline
\end{tabular}


readings were recorded into two separate text files, whereas the real-time $1 \mathrm{~s}$ data were not recorded but displayed in tabular and graphic forms for on-site and remote checking. Alarms, data collection notifications, data files, graphs, and statistics of daily data sets were automatically emailed to NCSU and Purdue at midnight. Timely action was taken to address any alarms or concerns observed when checking the real-time graphic or tabular data.

\section{EMisSion RATE DETERMinATION}

Custom-developed software, CAPECAB (Fibre Recovery Systems, Inc., Calgary, Alberta, Canada), was used to conduct data processing for emission rate calculation (Cortus et al., 2010). All the data were carefully checked for their validity before conducting further analysis and emission rate calculation. CAPECAB provided a robust method to inspect and validate data and implement various corrections over specific time periods when the QA/QC checks indicated a measurement bias.

\section{VENTILATION RATE DETERMINATION}

The airflow curves of all fans were obtained from the BESS Laboratory at the University of Illinois at UrbanaChampaign. Each performance record consisted of airflow $\left(Q_{1}\right)$ measured at several static pressures $\left(\Delta P_{1}\right)$ and at a relatively constant speed $\left(N_{1}=600\right)$. The BESS fan curve was adjusted to the mean speed of the fan tests $\left(N_{2}=\right.$ $570 \mathrm{rpm}$ ). The new, speed-indexed baseline curve was derived using the first and second fan laws as follows:

$$
\begin{aligned}
Q_{2} & =Q_{1}\left(N_{2} / N_{1}\right) \\
\Delta P_{2} & =\Delta P_{1}\left(N_{2} / N_{1}\right)^{2}
\end{aligned}
$$

where $Q_{2}$ is the speed-adjusted BESS fan airflow at speed $N_{2}$.

The speed-corrected airflow prediction model for a given test using the portable tester (FANS) is:

$$
Q_{3}=\left(a \Delta P_{3}+b\right) \times\left(N_{3} / N_{2}\right) \times Q_{2}
$$

where

$\Delta P_{3}=$ measured fan static pressure during the fan test

$N_{3}=$ measured fan speed during the fan test

$\left(a \Delta P_{3}+b\right)=$ fan degradation factor $k$

$Q_{3}=$ predicted airflow for the test using fitted fan model.

The resulting model for each fan's airflow was:

$$
\begin{aligned}
Q_{4} & =\left(N_{4} / N_{2}\right) \times\left[(1.38 \mathrm{E}-5) \Delta P_{4}^{3}+(4.86 \mathrm{E}-4) \Delta P_{4}^{2}\right. \\
& \left.+(6.10 \mathrm{E}-2) \Delta P_{4}+1.10 \mathrm{E}+1\right] \\
& \times\left[(3.94 \mathrm{E}-3) \Delta P_{4}+0.825\right]
\end{aligned}
$$

where

$\Delta P_{4}=$ pressure measured across that fan's wall

$N_{4}=$ measured rotational speed of the fan itself or the

average measured speed of other fans in the same ventilation stage

$Q_{4}=$ fan airflow used in calculation of emissions.

An "operational status" for each fan was based on the reading from its representative fan speed sensor or current switch. For those fans where speeds were measured, average $1 \mathrm{~min}$ records greater than $570 \mathrm{rpm}$ were treated as $100 \%$ on; anything less than $570 \mathrm{rpm}$ was assigned an operational status of $N_{3} / 570$. However, any $1 \mathrm{~min}$ record that was less than $55 \mathrm{rpm}$ was set to zero because several fan speed sensors had frequently exhibited low-level noiserelated values when fans were off.

\section{GAS EMisSion RATES}

In assessing house emission rates of $\mathrm{NH}_{3}, \mathrm{H}_{2} \mathrm{~S}$, and $\mathrm{CO}_{2}$, fans were assigned to a sampling stream based on their proximity to the sampling locations in each house. For each house, fans 1 to 8 and 18 to 25 (layer room of the east and west ends of the house) were defined as stream 1, fans 9 to 17 as stream 2 (manure pit of east end), and fans 26 to 34 as stream 3 (manure pit of west end). The airflow of each stream was calculated by summing the individual airflows of all fans in the stream.

The gas emission rate of a specific exhaust stream was calculated using equation 5. The total emission of a house was the summation of all the exhaust stream emissions for the house:

$$
E_{g}=\left[Q_{o} \frac{P_{o} \times M W}{R\left(273+T_{o}\right)}\right]\left(C_{o}-C_{i}\right)
$$

where

$$
\begin{aligned}
& E_{g}= \text { stream-specific gas emission rate }\left(\mathrm{mg} \mathrm{s}^{-1} \text { or } \mu \mathrm{g} \mathrm{s}^{-1}\right) \\
& Q_{o}= \text { stream moist airflow rate at } T_{o} \text {, i.e., the summation } \\
& \quad \text { of airflows of all fans in the stream }\left(\mathrm{m}^{3} \mathrm{~s}^{-1}\right) \\
& P_{o}=\text { stream exhaust air pressure }(\mathrm{atm})=\text { atmospheric } \\
& \quad \text { pressure }+ \text { differential static pressure } \\
& M W=\text { gas molecular weight }\left(\mathrm{g} \mathrm{mol}^{-1}\right) \\
& R=\text { ideal gas constant }(0.08206 \mathrm{~L}-\mathrm{atm} / \mathrm{mol}-\mathrm{K}) \\
& T_{o}=\text { stream exhaust air temperature }\left({ }^{\circ} \mathrm{C}\right) \\
& C_{o}=\text { stream exhaust air concentration }(\mathrm{ppm} \text { or ppb) } \\
& C_{i}=\text { air inlet concentration }(\mathrm{ppm} \text { or } \mathrm{ppb}) .
\end{aligned}
$$

For comparison purposes, the emission rate from an animal house is often expressed in terms of mass of pollutant per unit of time and per animal or per unit live mass of animal. In this study, based on flock sizes and hen weights, the gas emission rates of the house were converted into hen-specific $\left(\mathrm{g}^{-1} \mathrm{~d}^{-1}\right.$ hen) and live mass-specific $\left(\mathrm{g} \mathrm{d}^{-1}\right.$ $\mathrm{AU}^{-1}$ ) emission rates by dividing the house emission rate by the hen population and total live mass of the flock in $\mathrm{AU}$ (1 $\mathrm{AU}=500 \mathrm{~kg}$ live mass), respectively.

\section{PM EMISSION RATES}

Two strategies were used to measure PM concentrations and calculate PM emissions.

\section{Strategy 1: Single-stream method:}

All fans in a house were considered as one exhaust stream for PM emission calculation (eq. 6):

$$
E R_{S S}=\left[Q_{o} \frac{P_{o}}{P_{a t m}}\left(\frac{273+20}{273+T_{o}}\right)\right]\left(C_{o}^{\prime}-C_{i}^{\prime}\right)
$$

where

$$
E R_{S S}=\text { house } \mathrm{PM} \text { emission rate based on assigning all }
$$


fans to a single exhaust stream $\left(\mu \mathrm{g} \mathrm{s}^{-1}\right)$

$Q_{o}=$ house ventilation rate at $T_{o}$, i.e., the summation of airflows of all fans $\left(\mathrm{m}^{3} \mathrm{~s}^{-1}\right)$

$P_{o}=$ atmospheric pressure of exhaust air (atm)

$P_{\text {atm }}=$ standard atmosphere pressure $(1 \mathrm{~atm})$

$T_{o}=$ dry bulb exhaust air temperature $\left({ }^{\circ} \mathrm{C}\right)$

$C^{\prime}{ }_{o}=$ PM concentration of exhaust air measured in the manure pit and reported after correction to standard atmospheric conditions of $20^{\circ} \mathrm{C}$ and $1 \mathrm{~atm}\left(\mu \mathrm{g} \mathrm{m}^{-3}\right)$

$C^{\prime}{ }_{i}=$ inlet PM concentration measured by the beta gauge and reported after correction to standard atmospheric conditions $\left(\mu \mathrm{g} \mathrm{m}^{-3}\right)$.

\section{Strategy 2: Single-stream and dual-stream methods:}

During this period, the PM emission rate of house 4 was calculated with both the single-stream and dual-stream methods. The dual-stream method considered two separate emission streams. Air exhausted through the fans in the manure pit was defined as stream 1, and air exhausted from the layer room was stream 2. The airflow of each stream was calculated by summing fan airflows within the stream. In the dual-stream method, the PM emission rate of house 4 was calculated using equation 7 :

$$
\begin{aligned}
E R_{D S} & =\left[Q_{o 1} \frac{P_{o 1}}{P_{a t m}}\left(\frac{273+20}{273+T_{o 1}}\right)\right]\left(C_{o 1}^{\prime}-C_{i}^{\prime}\right) \\
& +\left[Q_{o 2} \frac{P_{o 2}}{P_{a t m}}\left(\frac{273+20}{273+T_{o 2}}\right)\right]\left(C_{o 2}^{\prime}-C^{\prime}\right)
\end{aligned}
$$

where

$E R_{D S}=$ house PM emission rate calculated using the dual-stream method $\left(\mu \mathrm{g} \mathrm{s}^{-1}\right)$

$Q_{o 1}$ and $Q_{o 2}=$ streams 1 and 2 exhaust airflow rates at $T_{o}$, i.e., the summation of fan airflows in the manure pit and layer room $\left(\mathrm{m}^{3} \mathrm{~s}^{-1}\right)$

$P_{o 1}$ and $P_{o 2}=$ pressure of exhaust air of streams 1 and 2 (atm)

$T_{o 1}$ and $T_{o 2}=$ temperature of exhaust air of streams 1 and $2\left({ }^{\circ} \mathrm{C}\right)$

$C^{\prime}{ }_{o 1}$ and $C^{\prime}{ }_{o 2}=\mathrm{PM}$ concentration of streams 1 and 2 exhaust air measured by the TEOMs located in the manure pit and layer room and reported after correction to standard atmospheric conditions $\left(\mu \mathrm{g} \mathrm{m}^{-3}\right)$.

For comparison purposes, the house PM emission rates were normalized to hen-specific $\left(\mathrm{g} \mathrm{d}^{-1} \mathrm{hen}^{-1}\right)$ and live massspecific $\left(\mathrm{g} \mathrm{d}^{-1} \mathrm{AU}^{-1}\right)$ emission rates.

\section{RESULTS AND DisCUSSION}

\section{GSS PERFORMANCE}

The GSS sampling flow rates under the dead-head condition ( 73 to $77 \mathrm{kPa}$ ) were significantly less than the $0.45 \mathrm{~L} \mathrm{~min}^{-1}$ threshold (table 13), thus ensuring that leakfree operation occurred under normal GSS manifold conditions $(-5,100$ to $-9,700 \mathrm{~Pa})$. Leakage flow rates with manual leak tests were lower than with automatic testing because of longer periods of vacuum status. All leak tests (tables 13 and 14, fig. 6) conducted during the study
Table 13. Entire sampling system leakage test: Flow measured with a

\begin{tabular}{|c|c|c|c|c|c|}
\hline \multirow{2}{*}{$\begin{array}{l}\text { Sampling } \\
\text { Location }\end{array}$} & \multirow{2}{*}{$\begin{array}{c}\text { Flow } \\
\text { Measurement } \\
\text { Location }^{\text {[a] }}\end{array}$} & \multicolumn{3}{|c|}{$\begin{array}{c}\text { Sampling Date } \\
(\mathrm{m} / \mathrm{d} / \mathrm{y})\end{array}$} & \multirow{2}{*}{$\begin{array}{l}\text { Sampling } \\
\text { Point }^{[\mathrm{b}]}\end{array}$} \\
\hline & & $9 / 24 / 07$ & $11 / 19 / 07$ & $1 / 15 / 09$ & \\
\hline \multirow{3}{*}{ 1: Inlet } & GSS & 4.30 & 4.24 & 4.70 & \multirow{2}{*}{ w/o cap } \\
\hline & GSL & 4.30 & 4.15 & 4.71 & \\
\hline & GSS & 0.05 & 0.18 & $<0.01$ & w/ cap \\
\hline \multirow{3}{*}{ 2: H3F4 } & GSS & 4.35 & 4.23 & 4.72 & \multirow{2}{*}{ w/o cap } \\
\hline & GSL & 4.35 & 4.17 & 4.77 & \\
\hline & GSS & 0.14 & 0.06 & $<0.01$ & w/ cap \\
\hline \multirow{3}{*}{ 3: H3F13 } & GSS & 4.35 & 4.24 & 4.71 & \multirow{2}{*}{ w/o cap } \\
\hline & GSL & 4.35 & 4.12 & 4.76 & \\
\hline & GSS & 0.06 & 0.11 & $<0.01$ & w/ cap \\
\hline \multirow{3}{*}{ 4: H3F30 } & GSS & 4.14 & 4.10 & 4.93 & \multirow{2}{*}{ w/o cap } \\
\hline & GSL & 4.20 & 4.06 & 4.52 & \\
\hline & GSS & 0.08 & 0.05 & $<0.01$ & w/ cap \\
\hline \multirow{3}{*}{ 5: H4F4 } & GSS & 4.34 & 4.23 & 4.71 & \multirow{2}{*}{ w/o cap } \\
\hline & GSL & 4.34 & 4.17 & 4.87 & \\
\hline & GSS & 0.05 & 0.05 & $<0.01$ & w/ cap \\
\hline \multirow{3}{*}{ 6: H4F13 } & GSS & 4.30 & 4.29 & 4.70 & \multirow{2}{*}{ w/o cap } \\
\hline & GSL & 4.40 & 4.19 & 4.76 & \\
\hline & GSS & 0.06 & 0.06 & $<0.01$ & w/ cap \\
\hline \multirow{3}{*}{ 7: H4F30 } & GSS & 4.03 & 4.07 & 4.52 & \multirow{2}{*}{ w/o cap } \\
\hline & GSL & 4.10 & 3.99 & 4.52 & \\
\hline & GSS & 0.26 & 0.12 & 0.012 & w/ cap \\
\hline
\end{tabular}
rotameter in $\mathrm{L} \mathrm{min}^{-1}$.

a] GSS = flow was measured just prior to GSS sampling manifold; $\mathrm{GSL}=$ flow was measured at various gas sampling points.

[b] w/o cap = sampling line was uncapped under normal sampling conditions; w/ cap = dead-head condition was created by capping sampling line inlet.

Table 14. Manual leak tests of GSS.

\begin{tabular}{ccc}
\hline $\begin{array}{c}\text { Date } \\
(\mathrm{m} / \mathrm{d} / \mathrm{y})\end{array}$ & $\begin{array}{c}\text { GSS Pressure } \\
(\mathrm{Pa})\end{array}$ & $\begin{array}{c}\text { Flow Rate } \\
\left(\mathrm{L} \mathrm{min}^{-1}\right)^{[\mathrm{a}]}\end{array}$ \\
\hline $3 / 5 / 09$ & $-73,559$ & $<0.01$ \\
$3 / 20 / 09$ & $-77,123$ & $<0.01$ \\
$4 / 27 / 09$ & $-76,158$ & $<0.01$ \\
$8 / 7 / 09$ & $-75,000$ & $<0.01$ \\
$11 / 24 / 09$ & $-73,122$ & $<0.01$ \\
\hline
\end{tabular}

[a] Rotameter detection limit $=10 \mathrm{~mL} \mathrm{~min}^{-1}$ or $0.01 \mathrm{~L} \mathrm{~min}^{-1}$.

indicated continuous leak-free status of the entire GSS system.

The performance audits of all the GSLs and the GSS indicated that the measured equilibrated concentrations of individual sampling lines agreed to within $10 \%$ of the known gas concentrations (table 15), thus confirming the integrity of the gas sampling system.

\section{Gas ANalyzer Checks ANd Calibrations}

The MDLs for $\mathrm{NH}_{3}, \mathrm{CO}_{2}$, and $\mathrm{H}_{2} \mathrm{~S}$, which were calculated as three times the standard deviation of the noise data collected during an equilibrated period of measuring calibration zero gas concentrations for up to $1 \mathrm{~h}$, were 0.39 ppm, $6.99 \mathrm{ppm}$, and $2.34 \mathrm{ppb}$, respectively (table 16). These values were very close to the manufacturer's stated MDLs of $0.2 \mathrm{ppm}, 1.5 \mathrm{ppm}$, and $6.0 \mathrm{ppb}$ for $\mathrm{NH}_{3}, \mathrm{CO}_{2}$, and $\mathrm{H}_{2} \mathrm{~S}$, respectively.

Models created for correcting readouts of gas analyzers such as $\mathrm{NH}_{3}$ (table 17) and $\mathrm{H}_{2} \mathrm{~S}$ (table 18) with the average responses of the analyzers to repeated zero and span gas checks exhibited little drifting. The $\mathrm{R}^{2}$ for the $\mathrm{NH}_{3}$ and $\mathrm{H}_{2} \mathrm{~S}$ MPCs exceeded 0.99 and 0.999 , respectively, indicating excellent linearity for gases in the ranges of 0 to $80 \mathrm{ppm}$ and 0 to $10,000 \mathrm{ppb}$ for $\mathrm{NH}_{3}$ and $\mathrm{H}_{2} \mathrm{~S}$, respectively (tables 19 and 20). 
Table 15. Entire sampling system performance audit results.

\begin{tabular}{|c|c|c|c|c|}
\hline $\begin{array}{c}\text { Date } \\
(\mathrm{m} / \mathrm{d} / \mathrm{y})\end{array}$ & $\begin{array}{c}\text { Challenge Gas } \\
\text { and Conc. }\end{array}$ & Location & $\begin{array}{l}\text { Measured } \\
\text { Conc. }\end{array}$ & $\begin{array}{c}\text { Diff. } \\
(\%)\end{array}$ \\
\hline \multirow[t]{8}{*}{$1 / 29 / 09$} & $\mathrm{NH}_{3}$ & GSS top & 77.5 & 0.00 \\
\hline & 80 ppm & $\mathrm{H} 3 \mathrm{~F} 4$ & 76.6 & -1.17 \\
\hline & & H3F13 & 76.5 & -1.29 \\
\hline & & $\mathrm{H} 4 \mathrm{~F} 4$ & 77.8 & 0.35 \\
\hline & & H4F13 & 77.9 & 0.49 \\
\hline & & H4F30 & 76.4 & -1.45 \\
\hline & & H3F30 & 75.1 & -3.04 \\
\hline & & Inlet & 73.4 & -5.25 \\
\hline \multirow[t]{8}{*}{$2 / 6 / 09$} & $\mathrm{H}_{2} \mathrm{~S}$ & GSS top & 461 & 0.00 \\
\hline & $440 \mathrm{ppb}$ & $\mathrm{H} 3 \mathrm{~F} 4$ & 453 & -1.71 \\
\hline & & H3F 13 & 439 & -4.73 \\
\hline & & H4F4 & 411 & -10.8 \\
\hline & & $\mathrm{H} 4 \mathrm{~F} 13$ & 433 & -6.02 \\
\hline & & H4F30 & 448 & -2.79 \\
\hline & & H3F30 & 443 & -3.98 \\
\hline & & Inlet & 462 & -0.10 \\
\hline \multirow[t]{8}{*}{$8 / 17 / 09$} & $\mathrm{CO}_{2}$ & Innova inlet & 4747 & 0.00 \\
\hline & 5000 ppm & H3F4 & 4758 & 0.23 \\
\hline & & H3F 13 & 4690 & -1.19 \\
\hline & & H4F4 & 4813 & 1.39 \\
\hline & & $\mathrm{H} 4 \mathrm{~F} 13$ & 4790 & 0.91 \\
\hline & & H4F30 & NA & NA \\
\hline & & H3F30 & 4790 & 0.91 \\
\hline & & Inlet & 4790 & 0.91 \\
\hline \multirow{7}{*}{$\begin{array}{l}11 / 17 / 09 \\
11 / 24 / 09, \\
\text { and } 1 / 5 / 10\end{array}$} & $\mathrm{NH}_{3}$ & Innova inlet & 70.4 & 0.00 \\
\hline & 80 ppm & H3F4 & 70.4 & 0.00 \\
\hline & & H3F 13 & 70.5 & 0.14 \\
\hline & & H4F4 & 70.3 & -0.14 \\
\hline & & H4F 13 & 71.2 & 1.16 \\
\hline & & H4F30 & 72.7 & 3.21 \\
\hline & & H3F30 & 71.9 & 2.13 \\
\hline
\end{tabular}

Table 16. Results of noise tests of the gas analyzers.

\begin{tabular}{ccccccc}
\hline Gas & Min. & Max. & SD & MDL & $\begin{array}{c}\text { Duration } \\
(\min )\end{array}$ & $\begin{array}{c}T_{\text {dew }} \\
\left({ }^{\circ} \mathrm{C}\right)\end{array}$ \\
\hline $\mathrm{NH}_{3} \mathrm{ppm}$ & 0.19 & 0.49 & 0.13 & 0.39 & 50 & -48.2 \\
$\mathrm{CO}_{2} \mathrm{ppm}$ & -6.1 & 4.60 & 2.33 & 6.99 & 30 & -50.4 \\
$\mathrm{SO}_{2} \mathrm{ppb}$ & 10.9 & 12.8 & 0.40 & 1.20 & 30 & -50.9 \\
$\mathrm{H}_{2} \mathrm{~S}$ ppb & -2.04 & 1.25 & 0.78 & 2.34 & 30 & -50.9 \\
\hline
\end{tabular}

Table 19. Results of MPCs for $\mathrm{NH}_{3}$ measurements.

\begin{tabular}{cccc}
\hline $\begin{array}{c}\text { Date } \\
(\mathrm{m} / \mathrm{d} / \mathrm{y})\end{array}$ & $\begin{array}{c}\text { No. of } \\
\text { Points }\end{array}$ & $\begin{array}{c}\text { Maximum } \mathrm{NH}_{3} \\
\text { Conc. }(\mathrm{ppm})\end{array}$ & $\mathrm{R}^{2}$ \\
\hline $9 / 10 / 07$ & 4 & 60 & 0.999 \\
$3 / 12 / 08$ & 5 & 80 & 0.999 \\
$3 / 19 / 08$ & 5 & 80 & 0.999 \\
$11 / 14 / 08$ & 5 & 80 & 0.999 \\
$1 / 23 / 09$ & 5 & 50 & 0.999 \\
$3 / 26 / 09$ & 5 & 80 & 0.999 \\
$8 / 20 / 09$ & 5 & 80 & 0.999 \\
\hline
\end{tabular}

Table 20. Results of MPCs for $\mathrm{H}_{2} \mathrm{~S}$ measurements.

\begin{tabular}{cccc}
\hline $\begin{array}{c}\text { Date } \\
(\mathrm{m} / \mathrm{d} / \mathrm{y})\end{array}$ & $\begin{array}{c}\text { No. of } \\
\text { Points }\end{array}$ & $\begin{array}{c}\text { Maximum } \mathrm{H}_{2} \mathrm{~S} \\
\text { Conc. }(\mathrm{ppb})\end{array}$ & $\mathrm{R}^{2}$ \\
\hline $9 / 10 / 07$ & 4 & 500 & 0.999 \\
$9 / 19 / 07$ & 4 & 500 & 0.999 \\
$11 / 28 / 07$ & 4 & 500 & 0.999 \\
$12 / 27 / 07$ & 4 & 4,000 & 0.999 \\
$1 / 18 / 08$ & 4 & 4,000 & 0.999 \\
$4 / 4 / 08$ & 2 & 500 & 1.000 \\
$7 / 30 / 08$ & 4 & 500 & 0.999 \\
$3 / 19 / 09$ & 4 & 500 & 0.999 \\
$9 / 1 / 09$ & 4 & 500 & 0.999 \\
$10 / 27 / 09$ & 4 & 500 & 0.999 \\
\hline
\end{tabular}

\section{PM MONITOR CHECKS}

The two TEOMs met all requirements of flow audits (main flow $=3.0 \pm 0.2 \mathrm{~L} \mathrm{~min}^{-1}$; total flow $=16.67 \pm 1.0 \mathrm{~L}$ $\min ^{-1}$ ) and leak checks (main flow $\leq 0.15 \mathrm{~L} \mathrm{~min}^{-1}$; total flow $\leq 0.62 \mathrm{~L} \mathrm{~min}^{-1}$ ) based on periodic quality assurance practice (tables 21 and 22). The mass verification tests of the TEOMs were all within $\pm 2.5 \%$ of $K_{o}$ audit, except for the test on 15 September 2009. The average differences between collocated TEOM tests were $8.7 \%$ for $\mathrm{PM}_{10}$ $(21.5 \mathrm{~h})$ and $9.2 \%$ for TSP $(91.5 \mathrm{~h})$, respectively (Li et al., 2012).

\section{RH/T SENSOR CHECKS}

The calibration checks of all RH/T sensors showed good agreements for both temperature and RH (fig. 7).

Table 17. Zero/span checks and concentration readout correction models for $\mathrm{NH}_{3}$.

\begin{tabular}{|c|c|c|c|c|c|c|c|}
\hline \multirow{3}{*}{$\begin{array}{l}\text { Period } \\
(\mathrm{m} / \mathrm{d} / \mathrm{y})\end{array}$} & \multirow{2}{*}{\multicolumn{2}{|c|}{ No. of Checks }} & \multirow[b]{3}{*}{ Linear Model $^{[\mathrm{a}]}$} & \multicolumn{4}{|c|}{ Accuracy (\% of span) } \\
\hline & & & & \multicolumn{2}{|c|}{ Bias } & \multicolumn{2}{|c|}{ Precision } \\
\hline & Zero & Span & & Zero & Span & Zero & Span \\
\hline $9 / 20 / 07$ to $11 / 19 / 07$ & 3 & 3 & $y=1.14 x-0.06$ & 0 & 0 & 1 & 3.3 \\
\hline $11 / 28 / 07$ to $1 / 4 / 08$ & 7 & 7 & $y=1.10 x-1.15$ & 0 & 0 & 0.2 & 3.1 \\
\hline $3 / 19 / 08$ to $10 / 10 / 08$ & 26 & 26 & $y=1.05 x-0.39$ & 0 & 0 & 0.2 & 2.4 \\
\hline $11 / 13 / 08$ to $1 / 16 / 09$ & 6 & 5 & $y=1.04 x-0.87$ & 0 & 0 & 0.3 & 0.6 \\
\hline $1 / 22 / 09$ to $3 / 26 / 09$ & 8 & 9 & $y=1.04 x-0.78$ & 0 & 0.1 & 0.3 & 0.8 \\
\hline $4 / 2 / 09$ to $8 / 13 / 09$ & 15 & 15 & $y=1.09 x-0.44$ & 0 & 0.3 & 0.5 & 2.6 \\
\hline $8 / 20 / 09$ to $10 / 20 / 09$ & 9 & 9 & $y=1.11 x-0.34$ & 0 & 0 & 0.3 & 0.7 \\
\hline
\end{tabular}

Table 18. Zero/span checks and concentration readout correction models for $\mathrm{H}_{2} \mathrm{~S}$.

\begin{tabular}{|c|c|c|c|c|c|c|c|}
\hline \multirow{3}{*}{$\begin{array}{l}\text { Period } \\
(\mathrm{m} / \mathrm{d} / \mathrm{y})\end{array}$} & \multirow{2}{*}{\multicolumn{2}{|c|}{ No. of Checks }} & \multirow[b]{3}{*}{ Linear Model $^{[\mathrm{a}]}$} & \multicolumn{4}{|c|}{ Accuracy $(\%$ of span $)$} \\
\hline & & & & \multicolumn{2}{|c|}{ Bias } & \multicolumn{2}{|c|}{ Precision } \\
\hline & Zero & Span & & Zero & Span & Zero & Span \\
\hline $9 / 20 / 07$ to $11 / 19 / 07$ & 3 & 4 & $y=1.00 x+4.05$ & 0 & 0 & 1 & 23.4 \\
\hline $11 / 28 / 07$ to $1 / 9 / 08$ & 5 & 1 & $y=0.88 x+0.67$ & 0 & 0 & 0 & 0 \\
\hline $1 / 18 / 08$ to $3 / 5 / 08$ & 0 & 0 & $y=0.84 x-6.64$ & 0 & 0 & 0 & 0 \\
\hline $3 / 7 / 08$ to $3 / 19 / 09$ & 48 & 43 & $y=1.04 x+0.31$ & 0 & 0 & 0.2 & 4.7 \\
\hline $3 / 26 / 09$ to $8 / 27 / 09$ & 19 & 4 & $y=2.03 x+1.20$ & 0 & 0 & 0.4 & 8.2 \\
\hline $9 / 1 / 09$ to $10 / 27 / 09$ & 7 & 7 & $y=0.87 x+0.55$ & 0 & 0 & 0.1 & 0.9 \\
\hline
\end{tabular}

[a] $x=$ instrument readout; $y=$ corrected readout. 
Table 21. Flow checks of TEOM 1.

\begin{tabular}{|c|c|c|c|c|c|c|}
\hline \multirow{2}{*}{$\begin{array}{c}\text { Date } \\
(\mathrm{m} / \mathrm{d} / \mathrm{y})\end{array}$} & \multirow{2}{*}{$\begin{array}{c}\text { Days } \\
\text { Since } \\
\text { Last } \\
\text { Test }\end{array}$} & \multirow{2}{*}{$\begin{array}{c}\text { Mass } \\
\text { Error } \\
(\%) \\
\left(K_{o} \text { audit }\right)\end{array}$} & \multicolumn{2}{|c|}{$\begin{array}{c}\text { TEOM } \\
\text { Flow Rates } \\
\left(\mathrm{L} \mathrm{min}^{-1}\right)\end{array}$} & \multicolumn{2}{|c|}{$\begin{array}{c}\text { Leak Test } \\
\text { Flow Rates } \\
\left(\mathrm{L} \text { min }^{-1}\right)\end{array}$} \\
\hline & & & Main & Total & Main & Aux. \\
\hline $11 / 20 / 07$ & 0 & - & 3.07 & 16.43 & 0.09 & 0.32 \\
\hline $7 / 18 / 08$ & 241 & 1.46 & 3.08 & 16.74 & 0.09 & 0.19 \\
\hline $10 / 17 / 08$ & 91 & 1.76 & 3.09 & 16.90 & 0.09 & 0.19 \\
\hline $11 / 26 / 08$ & 40 & - & 3.05 & 16.85 & 0.10 & 0.21 \\
\hline $1 / 23 / 09$ & 58 & 1.74 & 3.24 & 18.22 & 0.09 & 0.19 \\
\hline $2 / 27 / 09$ & 35 & 0.96 & 3.06 & 16.96 & 0.08 & 0.18 \\
\hline $5 / 21 / 09$ & 83 & 1.11 & 3.06 & 16.96 & 0.08 & 0.18 \\
\hline $9 / 15 / 09$ & 117 & 2.59 & 3.21 & 16.94 & 0.09 & 0.18 \\
\hline $10 / 27 / 09$ & 42 & - & 3.10 & 17.00 & 0.11 & 0.24 \\
\hline
\end{tabular}

Table 22. Flow checks on TEOM 2.

\begin{tabular}{|c|c|c|c|c|c|c|}
\hline \multirow{2}{*}{$\begin{array}{c}\text { Date } \\
(\mathrm{m} / \mathrm{d} / \mathrm{y})\end{array}$} & \multirow{2}{*}{$\begin{array}{c}\text { Days } \\
\text { Since } \\
\text { Last } \\
\text { Test }\end{array}$} & \multirow{2}{*}{$\begin{array}{c}\text { Mass } \\
\text { Error } \\
(\%) \\
\left(K_{o} \text { audit }\right)\end{array}$} & \multicolumn{2}{|c|}{$\begin{array}{c}\text { TEOM } \\
\text { Flow Rates } \\
\left(\mathrm{L} \mathrm{min}^{-1}\right)\end{array}$} & \multicolumn{2}{|c|}{$\begin{array}{l}\text { Leak Test } \\
\text { Flow Rates } \\
\left(\mathrm{L} \mathrm{min}{ }^{-1}\right)\end{array}$} \\
\hline & & & Main & Total & Main & Aux. \\
\hline $11 / 20 / 07$ & 0 & - & 3.03 & 16.8 & 0.10 & 0.41 \\
\hline $7 / 18 / 08$ & 241 & 1.85 & 3.03 & 16.5 & 0.09 & 0.41 \\
\hline $10 / 17 / 08$ & 91 & 2.33 & 3.04 & 16.7 & 0.09 & 0.40 \\
\hline $11 / 26 / 08$ & 40 & - & 3.01 & 16.7 & 0.10 & 0.41 \\
\hline $1 / 23 / 09$ & 58 & 1.58 & 3.04 & 16.6 & 0.09 & 0.40 \\
\hline $2 / 27 / 09$ & 35 & 2.22 & 3.03 & 16.6 & 0.09 & 0.41 \\
\hline $5 / 21 / 09$ & 83 & 2.40 & 3.00 & 16.5 & - & - \\
\hline $9 / 15 / 09$ & 117 & 4.48 & 3.05 & 16.9 & 0.09 & 0.42 \\
\hline
\end{tabular}

\section{Pressure Sensor Checks}

The differential pressure sensors showed $<1 \%$ offsets during the periodic zero checks (fig. 8). Excellent linearity $\left(\mathrm{R}^{2}>0.99\right)$ of the differential pressure sensor responses were observed for all three multipoint calibration events on 11 September 2007, 14 July 2008, and 7 September 2009 (fig. 9).

\section{House InVentory and Production CHARACTERISTICS}

Time series plots of flock size and hen weights are provided in figure 10 . The overall average feed and water consumption rates were about $80 \mathrm{~g} \mathrm{~d}^{-1} \mathrm{hen}^{-1}$ and $180 \mathrm{~mL} \mathrm{~d}^{-1}$ $\mathrm{hen}^{-1}$, respectively. The average egg production rate was 0.79 and 0.75 eggs d $^{-1}$ hen $^{-1}$ in houses 3 and 4 , respectively (fig. 11). The average hen weight was about $1.5 \mathrm{~kg}$ based on quarterly average hen weights, which were calculated from random samples of 40 hens weighed by the farm (fig. 10). The differences between the observed hen weights (random checks) and the inventory reports were $-5.2 \%$ and $-0.3 \%$ for houses 3 and 4 , respectively. The mortality rates, which were recorded daily, ranged from 9.4 to 19.6 per 100,000 hens. Results of the baseline emissions of PM and gaseous pollutants, ventilation rate, and impacts of the farm management activities are reported in parts II through IV of this series (Li et al., 2013a, 2013b; Wang-Li et al., 2013).

\section{SUMMARY}

Baseline air emissions from two high-rise tunnelventilated layer houses were monitored for two years at the Southeast Layer Site under the NAEMS, following an EPAapproved quality assurance project plan, which included a site monitoring plan and standard operating procedures. The targeted aerial emissions at this site were $\mathrm{NH}_{3}, \mathrm{H}_{2} \mathrm{~S}$, $\mathrm{CO}_{2}$, VOCs, and PM, including $\mathrm{PM}_{2.5}, \mathrm{PM}_{10}$, and TSP. In addition, operational and environmental variables (e.g., animal activity, indoor temperature and $\mathrm{RH}$, house ventilation rate, ambient temperature and $\mathrm{RH}$, wind speed and direction, and solar radiation) were monitored to

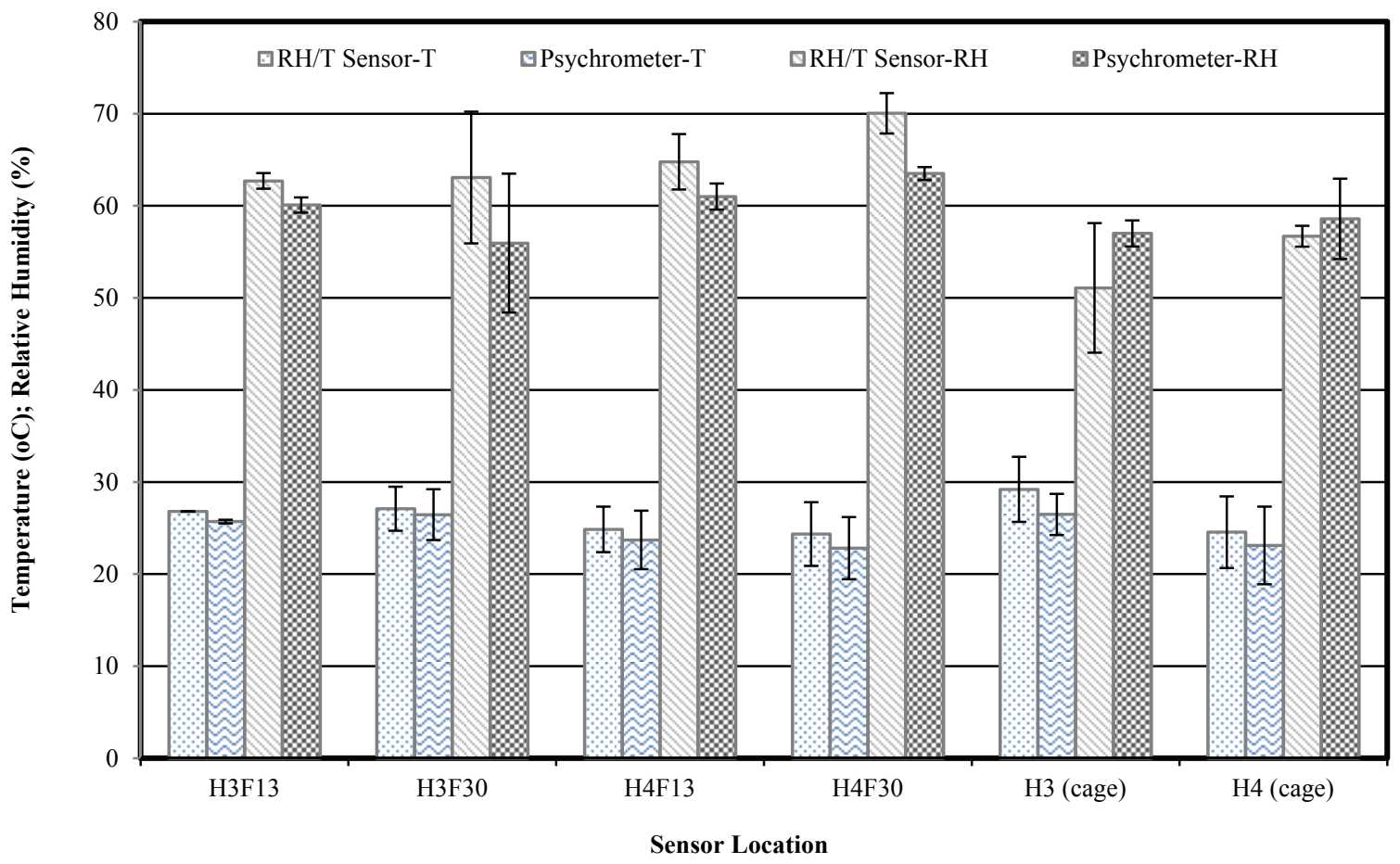

Figure 7. Results of RH/T sensor calibration checks (mean $\pm \mathrm{SD}$ ). 


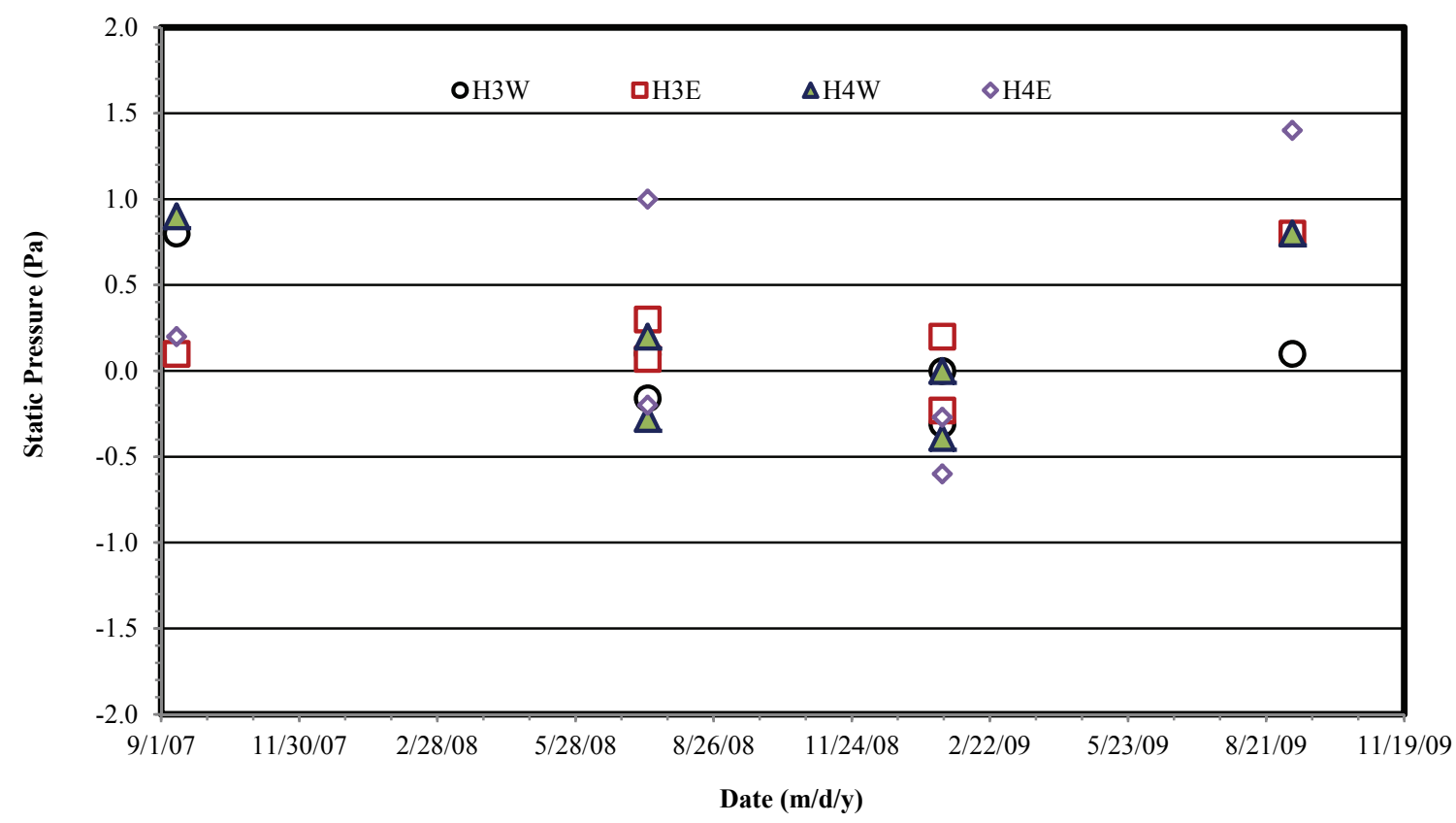

Figure 8. Zero checks of the differential pressure sensors.

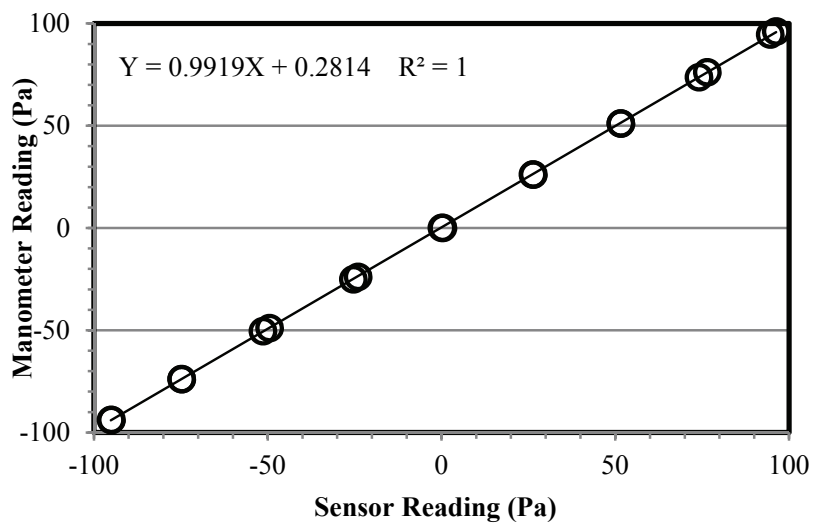

Figure 9. Multipoint calibration of the H3E differential pressure sensor on 11 September 2007. The $R^{2}$ values for the $\mathrm{H3W}, \mathrm{H} 4 \mathrm{E}$, and H4W sensors were $>0.99$. address their impacts on the emissions. Information about house inventory and major farm management activities was also collected. This article documents site characteristics and monitoring methods for the NAEMS at the Southeast Layer Site.

\section{ACKNOWLEDGEMENTS}

This study was supported by the Agricultural Air Research Council, the American Egg Board, and the National Science Foundation (NSF-CAREER Award No. CBET-0954673). The authors also acknowledge the generous support and collaboration of the egg producer.

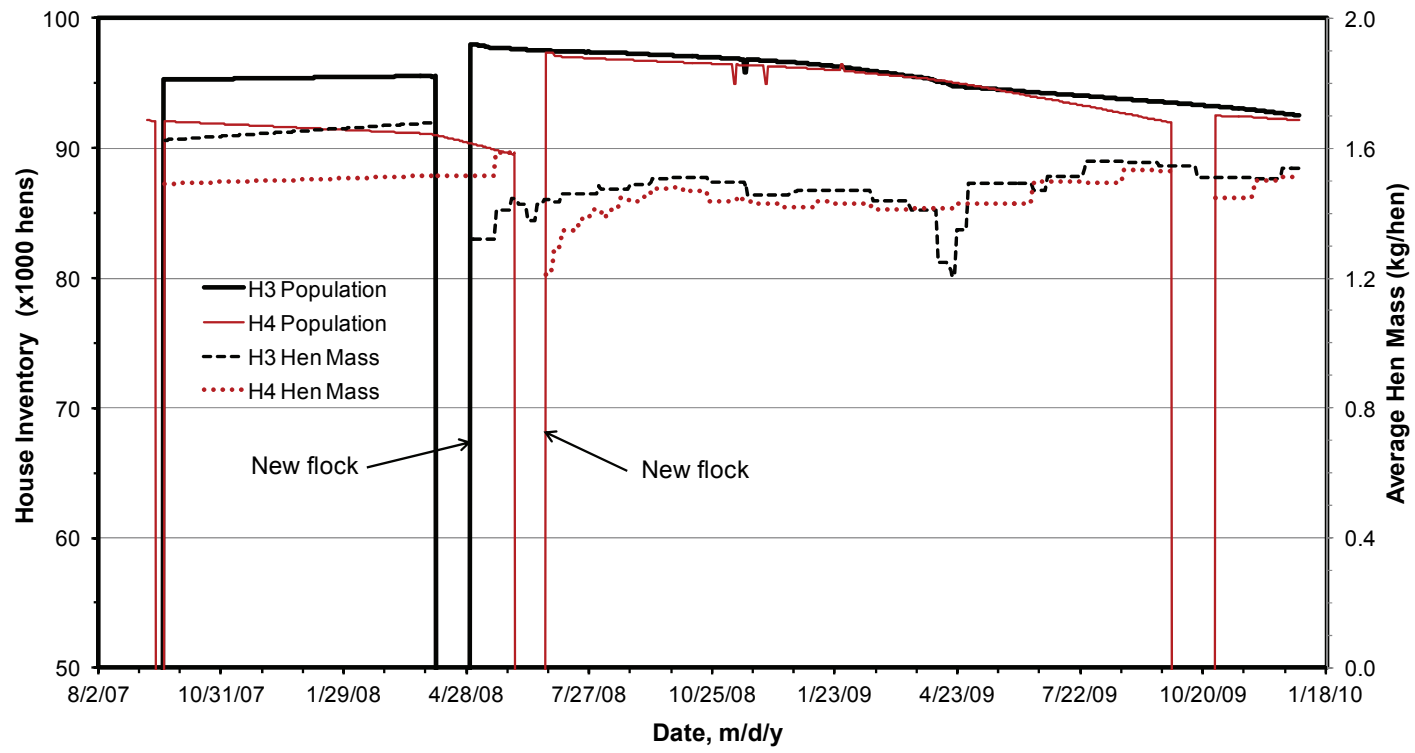

Figure 10. Inventory and average hen mass in houses 3 and 4. 


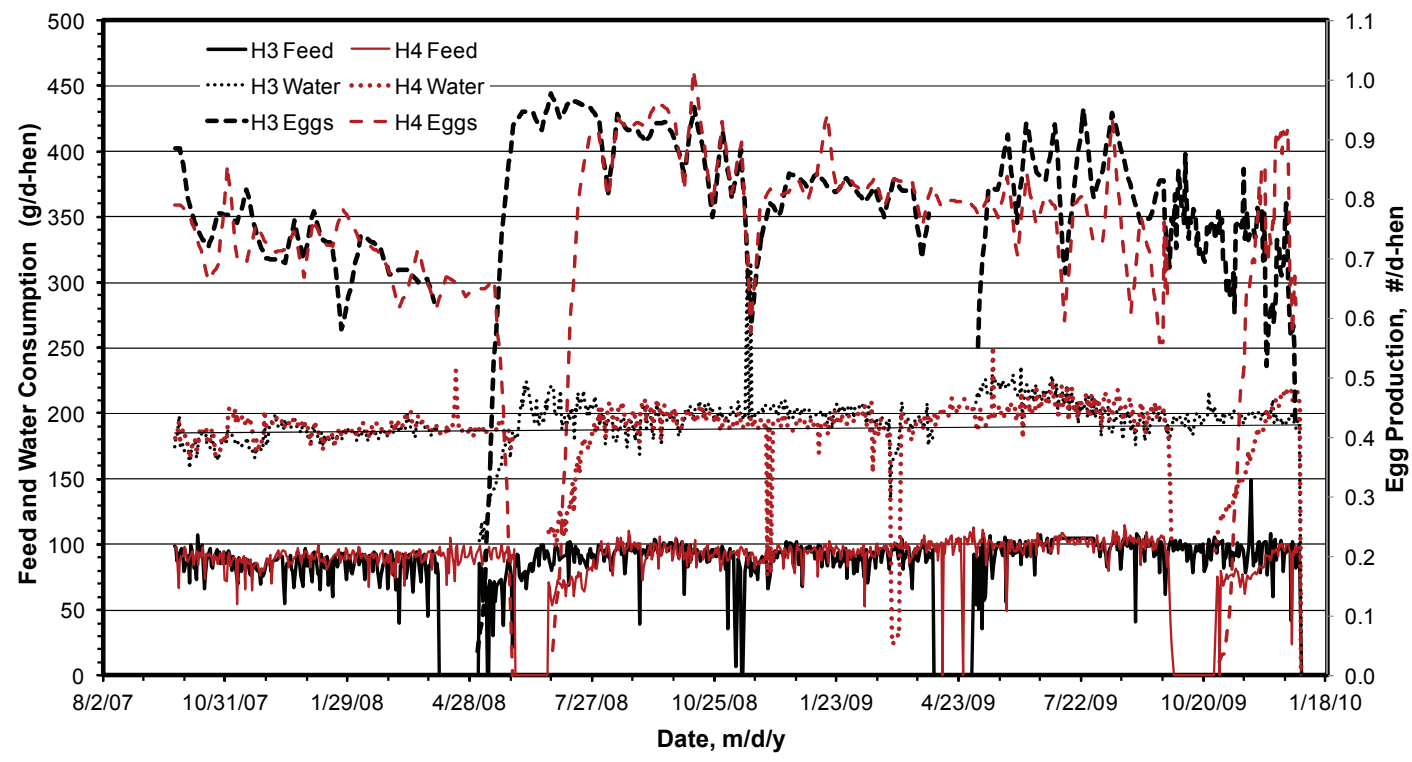

Figure 11. Feed and water consumption and egg production ( $7 \mathrm{~d}$ rolling average) in houses 3 and 4.

\section{REFERENCES}

Cortus, E. L., B. W. Bogan, K. Wang, T. T. Lim, J.-Q. Ni, M. A. Eisentraut, P. A. Eisentraut, and A. J. Heber. 2010. Using CAPECAB to process emission data in the National Air Emissions Monitoring Study. In Proc. Intl. Symp. on Air Quality and Manure Mgmt. for Agriculture. St. Joseph, Mich.: ASABE.

EPA. 1995. Emissions factors and AP 42, Compilation of air pollutant emission factors. Washington, D.C.: U.S. Environmental Protection Agency. Available at: www.epa.gov/ttn/chief/ap42/index.html. Accessed 6 June 2011.

EPA. 2001. Emissions from animal feeding operations (draft). EPA Contract 68-D-6-011. Washington, D.C.: U.S. Environmental Protection Agency.

EPA. 2004a. Ohio's largest egg producer agrees to dramatic air pollution reductions from three giant facilities. Washington, D.C.: U.S. Environmental Protection Agency. Available at: http://yosemite.epa.gov/opa/admpress.nsf/b1ab9f485b09897285 2562e7004dc686/508199b8068c24a585256e43007e1230!Open Document. Accessed 22 December 2012.

EPA. 2004b. Air emission characterization and management. Supporting documentation for the EPA regional science workshop on animal feeding operations (AFOs): Science and technical support needs, December 6-9, College Park, Md. Washington, D.C.: U.S. Environmental Protection Agency.

EPA. 2005. Animal feeding operation consent agreement and final order. Federal Register Vol. 70, No. 19. Washington, D.C.: U.S. Environmental Protection Agency. Available at: www.epa.gov/ compliance/resources/agreements/caa/cafo-agr.html. Accessed 4 January 2013.

Gates, R. S., K. D. Casey, H. Xin, E. E. Wheeler, and J. D. Simmons. 2004. Fan Assessment Numeration System (FANS) design and calibration specifications. Trans. ASAE 47(5): 17091715.

Heber, A. J., B. W. Bogan, J.-Q. Ni, T. T. Lim, E. L. Cortus, J. C. Ramirez-Dorronsoro, C. A. Diehl, S. M. Hanni, C. Xiao, K. D. Casey, C. A. Gooch, L. D. Jacobson, J. A. Koziel, F. M.
Mitloehner, P. M. Ndegwa, W. P. Robarge, L. Wang, and R. Zhang. 2008a. The National Air Emissions Monitoring Study: Overview of barn sources. In Proc. 8th Intl. Livestock Environment Symp. St. Joseph, Mich.: ASABE.

Heber, A. J., J.-Q. Ni, T.-T. Lim, and J. C. Ramirez. 2008b. Quality assurance project plan for the National Air Emissions Monitoring Study (barns component). West Lafayette, Ind.: Purdue University. Available at: www.epa.gov/airquality/ agmonitoring/ pdfs/afobroilereemreport2012draftappa.pdf. Accessed 5 December 2012.

Li, Q.-F., L. Wang-Li, Z. Liu, and A. J. Heber. 2012. Field evaluation of particulate matter measurements using tapered element oscillating microbalance in a layer house. J. Air and Waste Mgmt. Assoc. 62(3): 322-335.

Li, Q.-F., L. Wang-Li, K. Wang, L. Chai, E. L. Cortus, I. Kilic, B. W. Bogan, J.-Q. Ni, and A. J. Heber. 2013a. The National Air Emissions Monitoring Study's Southeast Layer Site: Part II. Particulate matter. Trans. ASABE 56(3): 1173-1184.

Li, Q.-F., L. Wang-Li, B. W. Bogan, K. Wang, L. Chai, J.-Q. Ni, and A. J. Heber. 2013b. The National Air Emissions Monitoring Study's Southeast Layer Site: Part IV. Effects of farm management. Trans. ASABE 56(3): 1199-1209.

Ni, J.-Q., and A. J. Heber. 2010. An on-site computer system for comprehensive agricultural air quality research. Computers and Electronics in Agric. 71(1): 38-49.

NRC. 2003. Air emissions from animal feeding operations: Current knowledge, future needs. Washington, D.C.: National Research Council.

UEP. 2010. Animal husbandry guidelines for U.S. egg laying flocks. 2010 ed. Alpharetta, Ga.: United Egg Producers. Available at www.unitedegg.org/information/pdf/UEP_2010_Animal_ Welfare_Guidelines.pdf. Accessed 12 December 2011.

Wang-Li, L., Q.-F. Li, L. Chai, E. L. Cortus, K. Wang, I. Kilic, B. W. Bogan, J.-Q. Ni, and A. J. Heber. 2013. The National Air Emission Monitoring Study's Southeast Layer Site: Part III. Ammonia concentrations and emissions. Trans. ASABE 56(3): $1185-1197$. 